Amasya Ilahiyat Dergisi - Amasya Theology Journal

ISSN 2667-7326 | e-ISSN 2667-6710

Aralık / December 2020, 15: 617-648

\title{
Dindarlık ile Eşler Arası Uyum Arasındaki İlişkinin İncelenmesi: Kahramanmaraş Örneği*
}

\section{Zeynep Sümeyye YILMAZ}

Kahramanmaraş Oniki Şubat Kürtül Ortaokulu Din Kültürü ve Ahlak Bilgisi Öğretmeni

Religious Culture and Moral Knowledge Instructor in Kahramanmaraş

Oniki Şubat Kürtül Secondary School

Kahramanmaras, Turkey

ze_su_ka@yahoo.com

orcid.org/0000-0002-0411-5548

\section{Halil APAYDIN}

Prof. Dr., Amasya Üniversitesi, İlahiyat Fakültesi, Din Bilimleri

Anabilim Dalı

Professor, Amasya University, Faculty of Theology,

Department of Science of Religion

Amasya, Turkey

halil.apaydin@amasya.edu.tr

orcid.org/0000-0001-8402-0428

\section{Büşra Nur YÜKSEL}

Arş. Gör., Amasya Üniversitesi, İlahiyat Fakültesi, Din Bilimleri

Anabilim Dalı

Research Assistant, Amasya University, Faculty of Theology,

Department of Science of Religion

Amasya, Turkey

busra.yuksel@amasya.edu.tr

https://orcid.org/0000-0003-0419-1732

* Etik Bildirim: Bu makale Yılmaz'ın 2018 yılında hazırlamış olduğu “Eşler Arası Uyum ve Dindarlık: Kahramanmaraş Örneği" adlı yüksek lisans tezinin bir bölümünden türetilmiştir. Ethical Statements: This article is produced from a part of the Yilmaz's master's thesis called as "Harmony between Married Couples and Religiosity: Example of Kahramanmaras" prepared in 2018. 
618 | Z. S. YILMAZ \& H. APAYDIN \&. B. N. YÜKSEL / Dindarlık ile Eşler Arası Uyum Arasındaki İlişkinin İncelenmesi: Kahramanmaraş Örneği

\section{Makale Bilgisi / Article Information}

Makale Türü / Article Types: Araştırma Makalesi / Research Article

Geliş Tarihi / Received: 15 Ekim / October 2020

Kabul Tarihi / Accepted: 16 Kasım / November 2020

Yayın Tarihi / Published: 30 Aralık / December 2020

Yayın Sezonu / Pub. Date Season: Aralık / December

Sayı / Issue: 15 Sayfa / Pages: 617-648

Atıf / Cite as: Yılmaz, Zeynep Sümeyye - Apaydın, Halil - Yüksel, Büşra Nur. “Dindarlık ile Eşler Arası Uyum Arasındaki İlişkinin İncelenmesi: Kahramanmaraş Örneği [Examining Relationship between Religiosity and Marital Adjustment: The Case Study in Kahramanmaras]". Amasya Ilahiyat Dergisi-Amasya Theology Journal 15 (December 2020): 617-648.

https://doi.org/10.18498/amailad. 811110.

Intihal / Plagiarism: Bu makale, en az iki hakem tarafından incelendi ve intihal içermediği teyit edildi. / This article has been reviewed by at least two referees and scanned via a plagiarism software.

Copyright (C) Published by Amasya Üniversitesi, İlahiyat Fakültesi / Amasya University, Faculty of Theology, Amasya, 05100 Turkey. All rights reserved. https://dergipark.org.tr/amailad.

\section{Examining Relationship between Religiosity and Marital Adjustment: The Case Study in Kahramanmaras}

\section{Abstract}

The concept of religion, which is one of the most common concepts in daily life, affects the lives of both individuals and societies. Since the holistic effect is thought to be also affected the marriage and family adjustment of individuals, the issue of marital adjustment and religiosity between spouses is important. In this study, the effect of religiosity on marital adjustment was evaluated along with various variables.

In this respect, the effects of religiosity on married individuals who have different religiosity level has been analyzed, and the effects also have been evaluated with some factors such as gender, age, educational status, economic status, working condition, number of children, duration of marriage, married style, and sources of religious education. In other words, the main problem of the research that "is there a relationship between the level of religiosity and marital adjustment (happiness in marriage) of the married individuals who are living in Kahramanmaras?", and the basic hypothesis was defined as "there is a 
significant positive relationship between religiosity and marital adjustment (happiness in marriage)".

In the research, the correlational model which is a quantitative research design was used and the survey form consisting of 'Personal and Sociodemographic Information Form' which contains sociodemographic factors such as gender, economic status and married styles has been created by author appropriate to the topic, 'Marital Adjustment Scale', formed by Almas and evaluates the level of marital adjustment between spouses, and 'Religiosity Scale' formed by Kula that evaluates the level of religiosity, has been conducted on a group which consist of 420 (218: F, 202: M) married individuals who are living in Kahramanmaras. After collecting the scores on scales of married individuals, the data was transferred to computer and SPSS 21 statistical program was used for the analysis of the data. The mean scores and standard deviations of religiosity was calculated, and Mann-Whitney U-test was used to determine whether the relations between two different groups was significant or not. Kruskal-Wallis $\mathrm{H}$ test was used to analyze the data obtained from comparison of more than two groups and for the analysis of the significant differences Spearman coefficient of correlation was used in order to determine the variation of correlation between two variables. For the testing of hypotheses, significance value (p) was taken as ,05.

The results show that $218(51,9 \%)$ of the participants were female and 202 $(48,1 \%)$ were male, at the same time $68(16,2 \%)$ participants were graduates of primary school, $36(8,6 \%)$ were of secondary school, $63(15 \%)$ were of high school, $216(51,4 \%)$ were of university and $37(8,8 \%)$ of them have master degree. In addition, $325(77,4 \%)$ participants had middle purchasing power, 45 $(10,7 \%)$ participants had lower purchasing power, and $50(11,9 \%)$ had high purchasing power. Also, the results determine that $103(24,5 \%)$ of the participants were unemployed, 50 (11,9\%) of them were worker, 225 (53,7\%) of them were officer, $16(3,8 \%)$ of them were trades, $1(0,2 \%)$ of them were farmer and $9(2,1 \%)$ of them were retired person. In addition, $165(39,3 \%)$ of the participants were married by the way of pre-arranged marriage, $157(37,4 \%)$ of them were married by the way of acquaintance and $98(23,3 \%)$ of them were married by the way of friend's proposal. The data in regard to the duration of marriage show that $23(5,5 \%)$ of participants have been married less than 1 year, $60(14,3 \%)$ of them were together from 1 to 3 years, $64(15,2 \%)$ of them were together from 4 to 6 years, 61 (14\%) of them were together from 7 to 9 years, and $212(50,5 \%)$ of them have been married for 10 years and more. Also the results 
620 | Z. S. YILMAZ \& H. APAYDIN \&. B. N. YÜKSEL / Dindarlık ile Eşler Arası Uyum Arasındaki İlişkinin İncelenmesi: Kahramanmaraş Örneği

in regard to the sources of religious education show that $131(31,2)$ of participants received from their family, $75(17,9)$ of them received from school, $156(37,1)$ of them received from mosque, $47(11,2)$ of them received from multiple sources.

In the study, also a positive significant correlation was found between the participants' scores of the rituals, knowledge, affective dimensions of religiosity and happiness in marriage. On the other hand, any significant correlation was found between the scores of the rituals, knowledge, belief sub-dimensions of religiosity and the unhappiness in marriage. Moreover, in the results of analyses, it is clearly found that there is a positive correlation between the scores of marital adjustment (happiness in marriage) and religiosity.

As a conclusion, the findings of this study showed that the married individuals in Kahramanmaras who stated to have more high religious level, experienced happiness in their marriage.

Keywords: Religiosity, Marital Adjustment, Happiness in Marriage, Problem in Marriage, Religious Activity.

\section{Dindarlık ile Eşler Arası Uyum Arasındaki İlişkinin İncelenmesi: Kahramanmaraş Örneği}

\section{Öz}

Günlük yaşamda en sık karşılaşılan kavramlardan biri olan din kavramı hem bireylerin hem de toplumların hayatını etkilemektedir. Bu bütüncül etkinin bireylerin evlilik ve aile içi uyum süreçlerine de yansıdığg düşünüldügünden, eşler arası uyum ve dindarlık konusu önem taşımaktadır. $\mathrm{Bu}$ sebepten araştırmada, dindarlığın eşler arası uyuma etkisi çeşitli değişkenler ile incelenmiştir.

$\mathrm{Bu}$ bağlamda, dindarlığın farklı dindarlık tonlarına sahip evli bireyler üzerindeki etkileri analiz edilmiş ve bu etkiler cinsiyet, yaş, eğitim durumu, ekonomik durum, çalışma koşulları, çocuk sayısı, evlilik süresi, evlilik tarzı ve dini eğitim kaynakları gibi bazı sosyodemografik faktörlerle birlikte değerlendirilmiştir. Yani araştırmanın temel sorunu, “Kahramanmaraş'ta yaşayan evli bireylerin dindarlık düzeyi ile evlilik uyumları (evlilikte mutluluk) arasında bir ilişki var mıdır?" ve temel hipotezi "dindarlık ile evlilik uyumu (evlilikte mutluluk) arasında anlamlı yönde pozitif bir ilişki vardır" olarak tanımlanmıştır.

Araştırmada nicel araştırma yöntemlerinden biri olan korelasyonel model kullanılmış ve konuya uygun olarak yazar tarafından cinsiyet, ekonomik 

durum, evlilik tarzları gibi sosyodemografik faktörlerden oluşturularak hazırlanan 'Kişisel ve Sosyodemografik Bilgi Formu', Almas tarafından oluşturulan ve eşler arasındaki evlilik uyumu düzeyini ölçen 'Evlilikte Uyum Ölçeği' ve Kula'nın oluşturduğu 'Dindarlık Ölçeği'ni içeren anket formu Kahramanmaraş'ta yaşayan 420 (218: K, 202: E) evli bireyden oluşan bir grup üzerinde uygulanmıştır. Evli bireylerin ölçeklerden aldıkları puanlar toplanarak veriler bilgisayara aktarılmış ve verilerin analizinde SPSS 21 istatistik programı kullanılmıştır. Ortalama dindarlık puanları ve standart sapmaları hesaplanmış ve iki farklı grup arasındaki ilişkilerin anlamlı olup olmadığını belirlemek için Mann-Whitney U testi kullanılmıştır. İkiden fazla grubun karşılaştırılmasından elde edilen verilerin analizinde Kruskal-Wallis $\mathrm{H}$ testi ve iki değişken arasındaki korelasyonun anlamlı olup olmadığını belirlemek için ise anlamlı Spearman korelasyon katsayısı kullanılmıştır. Hipotezlerin test edilmesi için anlamlılık değeri (p) ,05 olarak alınmıştır.

Analiz sonuçlarına göre katılımcıların 218'i (\%51,9) kadın, 202'si (\%48,1) erkek, 68'i (\%16,2) ilkokul, 36’sı (\%8,6) ortaokul, 63'ü (\%15) lise, 216’s1 (\%51,4) üniversite ve 37'si $(\% 8,8)$ yüksek lisans mezunudur. Ayrıca $325(\% 77,4)$ katılımcının orta satın alım gücüne, 45 (\%10,7) katılımcının düşük satın alım gücüne ve $50(\% 11,9)$ katılımcının yüksek satın alım gücüne sahip olduğu görülmektedir. Yine araştırma sonuçları katılımcıların 103'ünün (\%24,5) çalışmıyor, 50'sinin (\%11,9) işçi, 225'inin (\%53,7) memur, 16'sının (\%3,8) esnaf, 1'inin $(\% 0,2)$ çiftçi, 16'sının $(\% 3,8)$ emekli olduğunu belirlemiştir. Ek olarak, katılımcıların 165'i $(\% 39,3)$ görücü usulüyle, 157'si $(\% 37,4)$ kendisi tanışarak ve 98'i $(\% 23,3)$ de tanıdıkların önerisiyle tanışarak evlenmişlerdir. Evlilik süresi açısından veriler katılımcıların 23'ünün (5,5) 1 yıldan az, 60'ının (\%14,3) 1-3 yıl, 64'ünün (\%15,2) 4-6 y1l, 61'inin (\%14,5) 7-9 yıl ve 212'sinin (\%50,5) 10 y1l ve üzeri süre evli olduklarını göstermiştir. Ayrıca dinî eğitim aldıkları kaynaklara göre sonuçlar 131'inin $(\% 31,2)$ aile, 75'inin $(\% 17,9)$ okul, 156'sının $(\% 37,1)$ cami/Kur'an kursu ve $47^{\prime} \operatorname{sinin}(\% 11,2)$ diğer kaynaklardan dini eğitim aldıklarını göstermiştir.

Araştırmada ayrıca katılımcıların dindarlığın ritüel, bilgi, duyuşsal, etki boyutları ile evlilikte uyum (evlilikte mutluluk) arasında da pozitif yönde anlamlı bir ilişki bulunmuştur. Diğer taraftan, dindarlığın ritüel, bilgi, inanç boyutları ile evlilikte mutsuzluk arasında herhangi bir ilişki tespit edilememiştir. Bununla birlikte analiz sonuçlarında, evlilikte uyum (evlilikte mutluluk) ile dindarlık puanları arasında pozitif bir ilişki olduğu açıkça ortaya çıkmıştır. 
622 | Z. S. YILMAZ \& H. APAYDIN \&. B. N. YÜKSEL / Dindarlık ile Eşler Arası Uyum Arasındaki İlişkinin İncelenmesi: Kahramanmaraş Örneği

Sonuç olarak, bu çalışmanın bulguları, Kahramanmaraş'ta yüksek dindarlığa sahip olduğunu belirten evli bireylerin evliliklerinde mutluluk yaşadıklarını göstermiştir.

Anahtar Kelimeler: Dindarlık, Eşler Arası Uyum, Evlilikte Mutluluk, Evlilikte Sorun, Dinî Aktivite.

\section{Giriş}

Bireylerin yaşamında kuşatıcı niteliği ile var olan din gerek toplumsal gerekse bireysel yaşam alanlarında etkin bir role sahiptir. $\mathrm{Bu}$ kuşatıcı niteliğin yoğunluğu ise bireylerin dinî algılayış ve yaşayış derecelerine göre farklılaşmakta (Taş, 2006, 178) ve bu farklılaşma dindarlık kavramı ile ifade edilmektedir (Johnstone, 1992, 59-60; Köktaş, 1993, 62-66). Dinîn etkisini hayatının her alanında farklı tonlarda yaşayan bireyler aynı zamanda var oldukları toplumun sosyal olgularından biri olan aile kurumu ile birlikte psikoloji alanında inceleme konusu olmaktadır. Toplumun çekirdeğini oluşturan aile aynı zamanda dinî hayatın da canlı ve dinamik olarak yaşandığı bir kurumdur. Bu canlı yapının içerisinde eşlerin anlayış ve yaşayışının etkilendiği değerlerden biri olan din ile birlikte bu yapının devamı ve kalitesi için önem arz eden eşler arası uyum kavramı da son yıllarda üzerinde sıklıkla durulan bir konu olmuştur. Sonuç olarak, toplumun canlı ve dinamik bir yapıya sahip olmasının beraberinde getirdiği değişimler; aile kurumunu da derinden etkilemiş, evlilik ilişkilerinin niteliğinin değişmesine ve evlilikte yaşanan problemlerin farklılaşmasına yol açmış ve böylece eşler arası uyum sorunlarının tespit ve incelenmesinin de önemini artırmıştır.

Ailede eşlerin dindarlık düzeyi ve niteliği; evliliğin başlangıcını, sürdürülmesini ve evlilikteki mutluluk ile uyumu da etkileyebilmektedir. Evliliğin başlangıcından itibaren tüm aşamalarına doğrudan etkisinin olduğu bilinen dinîn, özellikle aile hayatını meşrûlaştırma işleviyle bireylerin yaşamlarında etkin bir role sahip olduğu görülmektedir (Çatak, 2012, 1; Apaydın - Kirman, 2004, 106). Çünkü aile, eşlerin psikososyal tüm farklılıklarıyla bütünleştikleri bir birlikteliktir ve bu birliktelikteki uyum, ailede olabilecek birçok soruna çözüm üretilmesinde kolaylık 
Marital Adjustment: The Case Study in Kahramanmaras I 623 sağlayacaktır. Bununla birlikte evliliğin toplumların büyük çoğunluğunda güçlü bir yapı olarak karşımıza çıktığını hesaba kattığımızda; biyolojik, psikolojik, sosyal ve kültürel temellerini iyi kavramak gerekmektedir (Tarhan, 2013, 13).

Küreselleşme sürecinin hız kazanması ile birlikte insanlar aile kurumundan ve dinden uzaklaşmakta, kişiler arası dayanışma yerini fırsatçılığa ve benmerkezciliğe; insan ilişkilerinde ise içtenlik ve samimiyet yerini yüzeysel davranışlara bırakmaktadır. Kişiler arası davranışlardaki niteliksel değişimin, bireylerin birbirlerine tahammül edemediği ve sorunların da aşılamadığı evliliklerin artmasının sebebi olduğu düşünülmektedir (Sayar, 2011, 103). Türkiye toplumunun aile yapısındaki problem alanlarından birini aile kurumundaki ahlâk ve değerlerin aşındırılması oluşturmaktadır (Demirkan, 2006, 92). Çünkü günümüzdeki modern değişimler beraberinde insanların maneviyât algılarını, dinî tutum ve yaşantılarını da değiştirmelerine ve dinî kalıpları sorgulamalarına yol açmaktadır. Dinîn yaşanan her türlü olumsuzluğun aşılmasında bir dayanak ve güç kaynağı olduğu düşüncesinin zayıflaması sebebiyle de evlilik dışı yaşantılar, artan boşanmalar ve ayrı yaşama gibi ailelerin üstesinden gelmekte zorlanacağ 1 birçok sorun ortaya çıkmaktadır (Cebeci, 2012, 169-170). Oysaki ailede bireylerin benimsedikleri manevi ve ahlâki değerler, aile içindeki uyumla yakından ilgilidir. Dindarlık ve eşler arası uyumu inceleyen çalışmalar; eşlerin dinî törenlere birlikte katılmalarının evlilik uyumu ile doğrudan etkili olduğunu, eşlerin düzenli olarak kiliseye gitmelerinin boşanma riskini düşürdügüünü ve dinîn eşleri ortak bir paydada buluşturarak demografik değişkenlerin dinîn etkisi ile kontrol edilebilir hale gelebileceğini hatta ortadan kalkabileceğini belirtmişlerdir (Call - Heaton, 1997, 382). Yine dindarlık düzeylerindeki artışın aile içi geçimsizliğin önlenmesi, çözümlenmesi ve üstesinden gelinmesinde katkı sağladığı tespit edilmiştir (Lambert - Dollahite, 2006, 593-594). Bununla birlikte eşlerin dinî inanç ve uygulamalarının birbirlerine bağlılık, başa çıkma, affetme, özveri gibi süreçler ile pozitif ilişkili olduğu ve aile içi geçim ile evlilik kalitesinin korunmasındaki önemi ortaya konmuştur (Goodman vd., 2013, 820-821). Eşlerin yaşamlarındaki değerlerin benzerlik derecesinin de evlilik uyumunu arttırdığ 1 
624 | Z. S. YILMAZ \& H. APAYDIN \&. B. N. YÜKSEL / Dindarlık ile Eşler Arası Uyum Arasındaki İlişkinin İncelenmesi: Kahramanmaraş Örneği

(Şener - Terzioğlu, 2008, 9) ve farklı dinî mezheplere mensup eşlerin dinî uygulamalarındaki farklılıklardan kaynaklı problemlerin ise evlilik uyumlarını azalttığı tespit edilmiştir (Almas, 2010, 67-68; Çatak, 2012, 199-200). Bununla birlikte aile hayatının dinîn de dahil olduğu değerler çerçevesinde yaşanması gerektiğini düşünenlerin toplumun çoğunluğunu oluşturduğu belirlenmiştir (BASAGM, 2010, 134). Bu düşünceler ışığında gerçekleştirilen evliliklerde de eşlerin manevi hedeflerinin aynılaşması ve aynı hedefler için ortak karar ile davranış sergilemeleri beklenmekte ve bu davranış tarzının evlilik yaşamını kaliteli kılabileceği gibi mutlu ve uyumlu bir birliktelik sağlayacağı düşünülmektedir (Tarhan, 2013, 29). Evlilikleri uyumlu devam eden eşlerin sorunlarını ve çatışmalarını da daha kolaylıkla onarabilecekleri açıktır. Evlilik uyumunun bozulmasında ise eşler travma yaşayabilmektedirler (Fidanoğlu, 2007, 5). Bireylerin yaşadıkları travmaların psikolojik tedavi süreçlerinde dinî anlama ve yaşama bakımından eşler arasındaki durumun ortaya konulması da süreçleri daha verimli hale getirecektir. Çünkü toplumsal ve bireysel değer tercihleri, maneviyat ve bireylerin öznel mutlulukları ile evlilik uyumları arasında yakın bir ilişki vardır (Kublay - Oktan, 2015, 29). Evliliklerin daha sürdürebilir olması için eşlerin uyumunun korunması ve geliştirilmesi gerekmektedir. Bu sebepten mevcut araştırmada hem dindarlığın eşlerin uyumuna hem de dinî anlayışın ve yaşayışın evlilikteki psikolojik ihtiyaçlara ve beklentilere olan etkisinin incelenmesi amaçlanmaktadır.

Dindarlık ve eşler arası uyum konulu alan araştırması olarak tasarlanan bu araştırmada, "evli bireylerin dindarlık ve eşler arası uyum düzeyleri arasında ilişki" çeşitli değişkenler ile birlikte incelenmiştir. Başka bir ifadeyle, araştırmanın temel problemini, "Kahramanmaraş ilindeki evli bireylerin dindarlık ile eşler arası uyum düzeyleri arasında bir ilişki var mıdır?" sorusu teşkil etmektedir. Araştırmanın temel hipotezi ise "dindarlık ve eşler arası uyum arasında pozitif yönde anlamlı bir ilişki vardır" şeklinde belirlenmiştir.

\section{Yöntem}

$\mathrm{Bu}$ çalışma, dindarlığın eşler arası uyuma etkisini ölçmek amaçlı var olan bir durumu belirlemeye yönelik yapılan tarama modeli ile tasarlanmış ve veri toplama aracı olarak anket tekniği 
kullanılmıştır. Bu sebeple, bu bölümde araştırmanın modeli, evren ve örneklemin niteliği, veri toplama araçları, verilerin toplanması ve analizi ile ilgili bilgiler verilecektir.

\subsection{Araştırmanın Modeli}

$\mathrm{Bu}$ çalışmada nicel araştırma desenlerinden korelasyonel araştırma modeli kullanılmış ve modele uygun bir şekilde Kahramanmaraş merkezde yaşayan evli bireylerin hem dindarlık ve eşler arası uyum düzeylerinin sosyodemografik değişkenlere göre farklılaşıp farklılaşmadığ 1 tespit edilmiş hem de dindarlık ve eşler arası uyum arasındaki ilişki belirlenmiştir.

\subsection{Evren ve Örneklem}

Araştırmanın evreni, Kahramanmaraş merkezde yaşayan evli bireylerden oluşmaktadır. Evreni temsilen belirlenen çalışma örneklemi ise Kahramanmaraş merkezde yaşayan orta yaştaki evli 420 bireydir. Bu çerçevede anket soruları tesadüfi olarak belirlenen 455 evli bireye uygulanmış; 35 anket eksik ve tutarsız cevaplar sebebiyle değerlendirmeye alınmamış ve 420 kullanılabilir anket formu üzerinden çalışma sürdürülmüştür.

Verilere göre katılımcıların hem sosyodemografik hem de evlilik ve dindarlık ile ilgili çeşitli değişkenlere göre dağılımı verilmiştir. Buna göre 420 katılımcının 218'i (\%51,9) kadın ve 202'si $(\% 48,1)$ erkek; 36'sı $(\% 8,6)$ 20-25 yaş, 81'i $(\% 19,3)$ 26-30 yaş, 118'i $(\% 28,1)$ 31-35 yaş, 80'i (\%19,0) 36-40 yaş, 32'si $(\% 7,6)$ 41-45 yaş ve 73 '̈u $(\% 17,4) 46$ yaş ve üzerinde; 68'i $(\% 16,2)$ ilkokul, 36'sı $(\% 8,6)$ ortaokul, 63'ü (\%15) lise, 216's1 (\%51,4) üniversite ve 37'si $(\% 8,8)$ yüksek lisans mezunudur. Yaşamın çoğunun geçirildiği yer değişkenine göre ise katılımcıların 330'u $(\% 78,6)$ ilde, 58'i $(\% 13,8)$ ilçede ve 32 'si $(\% 7,6)$ kasaba/köyde yaşamaktadır. Mesleklerine göre; 103'ü $(\% 24,5)$ çalışmıyor, 50'si $(\% 11,9)$ işçi, 225'i (\%53,7) memur, $16^{\prime}$ s1 $(\% 3,8)$ esnaf, 1'i $(\% 0,2)$ çiftçi, $16^{\prime}$ s1 $(\% 3,8)$ emeklidir. Gelir durumu değişkenine göre ise $45^{\prime} \mathrm{i}(\% 10,7)$ orta altı, 325'i $(\% 77,4)$ orta ve 50 'si $(\% 11,9)$ orta üstüdür.

Katılımcıların evlilikleri ile ilgili dağılımlarına bakıldı̆̆ında; eşler arası yaş farkında 420 katılımcının, 54'ü (\%12,9) fark yok, 152 'si $(\% 36,2) 1-3$ yaş, 120'si $(\% 28,6) 4-6$ yaş, 61'i $(\% 14,5)$ 7-9 yaş ve $33^{\prime}$ ü $(\% 7,8) 10$ yaş ve üzeri; evlilik süresine göre $23^{\prime}$ ü $(5,5) 1$ yıldan az, 60'ı (\%14,3) 1-3 yıl, 64'ü (\%15,2) 4-6 yıl, 61'i (\%14,5) 7-9 yıl ve 
626 | Z. S. YILMAZ \& H. APAYDIN \&. B. N. YÜKSEL / Dindarlık ile Eşler Arası Uyum Arasındaki İlişkinin İncelenmesi: Kahramanmaraş Örneği

212'si (\%50,5) 10 yil ve üzeri; evlenme şekline göre 165'i $(\% 39,3)$ görücü usulüyle, 157'si $(\% 37,4)$ kendisi tanışarak ve 98'i $(\% 23,3)$ tanıdıkların önerisiyle tanışarak evlenme olarak; eş seçim ölçütlerinde ise 56'sının $(\% 13,4)$ fiziksel çekicilik, 23'ünün (\%5.5) zeki olma, 17'sinin (\%4.0) soylu bir aileden gelme, 315'inin (\%75,0) dindar ve ahlâklı olma ve 9'unun (\%2.1) iyi gelir sahibi olma ölçütüne dikkat ederek dağılım gösterdikleri belirlenmiştir.

Katılımcıların dindarlık ile ilgili dağılımlarına bakıldığında; dinî eğitim aldıkları kaynaklara göre 131'i (\%31,2) aile, 75'i (\%17,9) okul, 156's1 $(\% 37,1)$ cami/Kur'an kursu, 11'i $(\% 2,6)$ dinî eğitim almama ve $47^{\prime}$ si $(\% 11,2)$ diğer kaynaklar olarak; çocuğunun dinî eğitim almasını isteme durumuna göre; 401'i (\%95,5) evet, 16's1 $(\% 3,8)$ kararsızım ve 3'ü $(\% 0,7)$ hayır; "eşlerden her ikisinin dindar olması evlilikte mutluluk için tek başına yeterlidir" değişkeninde katılımcıların 164' ünün $(\% 39,0)$ yeterli, 69'unun $(\% 16,4)$ kararsız ve 187 'sinin $(\% 44,6)$ yetersiz olarak dağıldığı görülmektedir. Bununla birlikte ailecek camiye gitme değişkenine göre katılımcıların $26^{\prime}$ sinin $(\% 6,1)$ her zaman, 264'ünün $(\% 62,9)$ bazen ve 130'unun (\%31) hiçbir zaman camiye gitmediği; evde dinî konular konuşma değişkenine göre 70'inin $(\% 16,6)$ her zaman, 259'unun $(\% 61,7)$ bazen ve 91 'inin $(\% 21,7)$ hiçbir zaman olarak; eş için dua etme değişkenine göre $296^{\prime}$ sinin $(\% 70,5)$ her zaman, 116'sinin $(\% 27,6)$ bazen ve $8^{\prime}$ inin $(\% 1,9)$ ise hiçbir zaman dua etmediği görülmüştür. Evde Kur'an okuma değişkeninde ise $142^{\prime} \operatorname{sinin}(\% 33,8)$ her zaman, 256'sının (\%61) bazen okuduğu ve 22 'sinin $(\% 5,2)$ hiçbir zaman Kur'an okumadığ1 belirlenmiştir.

\subsection{Veri Toplama Araçları}

Kişisel verilerin elde edildiği, eşler arası uyumun belirlendiği ve dindarlığın ölçüldüğü bölümler olmak üzere çalışmadaki anket üç bölümden oluşmaktadır. Bireylerin demografik bilgileri, dinî eğitimlerini nereden aldıkları, kaç yıllık evli oldukları, eşleriyle aralarındaki yaş farkı, çocuk sahibi olma durumları, eşlerini seçmedeki ölçütleri, çocuklarının dinî eğitim almalarını isteyip istememeleri, dinî ortamlara katılma durumları, dindarlığın evlilikteki mutluluğu etkilediği fikrine katılıp katılmama durumları, ailelerindeki dinî yaşamın gelişmesi için yaptıkları, evlenme 
şekilleri ve ailede dinî etkinlik yapma sıklıklarının sorulduğu 19 sorudan elde edilmiştir.

Araştırmada eşler arası uyum düzeyleri; eşler arası iletişim, evlilikte mutluluk ve mutsuzluk düzeyi, eşlerin sorun yaşama sıklıkları ile evlilikte sorun alanları üzerinden belirlenen ve Almas (2010, 82-98) tarafından geliştirilen 23 soruluk beşli Likert tipi ölçek ile belirlenmiştir. Evlilikte mutluluk ve sorun puanlarına ait iç tutarlılık analiz sonucu, ankete verilen cevapların güvenilir olduğunu belirtmektedir.

Katılımcıların dindarlık düzeylerini belirlemek için ise Kula (2001)'nın geliştirdiği 'Dindarlık Envanteri'nden faydalanılmıştır. Sevindik, dindarlık envanterine eklediği sorularla birlikte güvenirlik ve geçerlilik çalışması yapmış ve dindarlık envanterinin 6. maddesi olan 'Cuma namazı kadın, erkek, çocuk, büyük her Müslüman'a farzdır' ile 12. maddesinde yer alan 'Cuma namazlarına sürekli gidemiyorum' ifadelerini bu cümlelerin daha çok erkeklere hitap ettiği düşüncesiyle anketten çıkarmıştır. Bu maddelerin yerine, dinîn bilgi boyutunu içeren, 'Hac ibadeti, maddi ve bedeni durumu müsait olanların yerine getirmesi gereken bir dinî görevdir' ile 'İnsan, kazancının bir kısmını fakirlere zekât ve sadaka olarak vermelidir' maddelerini eklemiş ve çalışmada kullanılan dindarlık envanterine son şeklini vermiştir (Sevindik, 2015, 65). Dindarlık envanterinin alt boyutları için iç tutarlılık katsayıları ,332 ile ,765 arasında hesaplanmıştır. Envanterin genelinde verilen yanıtların güvenilir olduğu belirlenmiştir.

\subsection{Verilerin Analizi}

Çalışmanın uygulama bölümü Likert tipi sorulardan oluşan anket ile oluşturulmuştur. Elde dilen veriler SPSS Statistics 21.0 ve Microsoft Office Excel 2013 incelenmiştir. Çalışmada yer alan dindarlık envanterinin dağılımı Shapiro-Wilk testi ve normallik grafikleri ile incelenmiştir. Dindarlık envanteri, dinî aktivite ve evlilikte mutluluk/sorun puanlarının genel dağılımı; ortalama \pm standart sapma (ort \pm s) ve ortanca (min.-mak.) ile cinsiyet ve yaş grupları gibi kategorik değişkenlerin dağılımı ise sayı (\%) ile gösterilmiştir.

Dindarlık envanteri ve evlilikte mutluluk/sorun puanları; sosyodemografik değişkenler ile karşılaştırılırken, oluşan grup 
628 | Z. S. YILMAZ \& H. APAYDIN \&. B. N. YÜKSEL / Dindarlık ile Eşler Arası Uyum Arasındaki İlişkinin İncelenmesi: Kahramanmaraş Örneği

sayısına bağlı olarak Mann-Whitney U testi ve Kruskall Wallis testi kullanılmıştır. Kruskall-Wallis testinin anlamlı sonuç vermesi durumunda grupların ikili karşılaştırmaları Bonferroni düzeltmeli Mann-Whitney U testi ile yapılmıştır. Dindarlık envanteri ve dinî aktivite puanları ile evlilikte mutluluk/sorun puanları arasındaki ilişkiler Spearman korelasyon analizi ile incelenmiştir. Dindarlık envanteri, dinî aktivite ve evlilikte mutluluk/sorun soruları için iç tutarlılık Cronbach alfa değeri hesaplanmıştır. İstatistiksel anlamlılık düzeyi ise $\mathrm{p} \leq, 05$ olarak kabul edilmiştir.

\section{Bulgular}

$\mathrm{Bu}$ bölümde gerçekleştirilen istatistiksel analizlerin sonuçları yer almakta ve elde edilen bulgular üç ana başlık altında sunulmaktadır. İlk bölümde dindarlık ile çeşitli değişkenler arasındaki ilişkileri, ikinci bölümde evlilik içi uyum ile çeşitli değişkenler arasındaki ilişkileri ve üçüncü bölümde dindarlık ile evlilik içi uyum arasındaki ilişkileri belirlemek amacıyla yapılan analiz sonuçlarına yer verilmiştir.

\section{Dair Bulgular \\ 2.1. Dindarlık ile Çeşitli Değişkenler Arasındaki İlişkilere}

Bu bölümde, dindarlık envanteri alt boyutları ile katılımcıların hem sosyodemografik hem de evlilik ve dindarlık ile ilgili çeşitli değişkenler arasındaki ilişkilere dair sürdürülen analizler yer almaktadir.

Tablo 1: Çeşitli Değişkenlerin Dindarlık Envanterine Göre Dağılımına İlişkin Analiz Sonuçları

\section{DINDARLIK BOYUTLARI}

\begin{tabular}{lllllll} 
& İnanç & I. Önemi & İbadet & Duygu & Bilgi & Etki \\
\hline \multicolumn{2}{c}{ Çocuk Sayısı } & & & & & \\
Yok & 20 & 16 & 19 & 11 & 29 & 19 \\
& $(18-20)$ & $(9-20)$ & $(15-20)$ & $(7-15)$ & $(25-30)$ & $(15-20)$ \\
\multirow{3}{*}{ çocuk } & 20 & 16 & 18 & 11 & 29 & 19 \\
& $(13-20)$ & $(9-20)$ & $(9-20)$ & $(7-15)$ & $(19-30)$ & $(11-20)$ \\
2 çocuk & 20 & 17 & 18 & 12 & 29 & 19 \\
& $(13-20)$ & $(6-20)$ & $(9-20)$ & $(7-15)$ & $(21-30)$ & $(6-20)$ \\
3 çocuk & 20 & 17 & 19 & 11 & 29 & 20 \\
& $(16-20)$ & $(4-20)$ & $(12-20)$ & $(8-15)$ & $(23-30)$ & $(12-20)$ \\
+3 çocuk & 20 & 17 & 19 & 12 & 29 & 20 \\
& & & & &
\end{tabular}


Z. S. YILMAZ \& H. APAYDIN \&. B. N. YÜKSEL / Examining Relationship between Religiosity and Marital Adjustment: The Case Study in Kahramanmaras I 629

\begin{tabular}{|c|c|c|c|c|c|c|}
\hline & $(16-20)$ & $(11-20)$ & $(14-20)$ & $(7-15)$ & $(24-30)$ & $(16-20)$ \\
\hline$P$ &, 598 & ,086 &, $001^{*}$ &, 081 &, 169 &, $042^{*}$ \\
\hline \multicolumn{7}{|c|}{ Evlilik Şekli } \\
\hline Görücü & 20 & 17 & 19 & 12 & 29 & 20 \\
\hline usulü & $(14-20)$ & $(4-20)$ & $(12-20)$ & $(7-15)$ & $(21-30)$ & $(12-20)$ \\
\hline Kendimiz & 20 & 16 & 18 & 11 & 29 & 19 \\
\hline tanışarak & $(13-20)$ & $(6-20)$ & $(9-20)$ & $(7-15)$ & $(19-30)$ & $(6-20)$ \\
\hline Tanıdık & 20 & 17 & 19 & 11 & 29 & 19 \\
\hline önerisi & $(18-20)$ & $(7-20)$ & $(13-20)$ & $(7-15)$ & $(23-30)$ & $(15-20)$ \\
\hline$P$ & ,109 & 462 &, $009 *$ & ,333 & ,305 &, $028 *$ \\
\hline \multicolumn{7}{|c|}{ Eş Seçim Kriteri } \\
\hline Fiziksel & 20 & 16 & 18 & 11 & 29 & 19 \\
\hline Çekicilik & $(16-20)$ & $(7-20)$ & $(9-20)$ & $(8-15)$ & $(22-30)$ & $(6-20)$ \\
\hline Zeki & 20 & 16 & 16 & 11 & 27 & 18 \\
\hline olma & $(13-20)$ & $(4-20)$ & $(9-20)$ & $(7-15)$ & $(19-30)$ & $(11-20)$ \\
\hline Soylu & 20 & 18 & 18 & 12 & 29 & 19 \\
\hline olma & $(16-20)$ & $(12-20)$ & $(9-20)$ & $(9-15)$ & $(24-30)$ & $(15-20)$ \\
\hline Dindar & 20 & 17 & 19 & 12 & 29 & 20 \\
\hline olma & $(14-20)$ & $(7-20)$ & $(12-20)$ & $(7-15)$ & $(21-30)$ & $(13-20)$ \\
\hline İyi geliri & 20 & 17 & 20 & 12 & 29 & 20 \\
\hline olma & $(13-20)$ & $(6-20)$ & $(14-20)$ & $(9-15)$ & $(21-30)$ & $(15-20)$ \\
\hline$P$ &, 575 & ,124 &, $027^{*}$ &, $034^{*}$ & ,102 &, $005^{*}$ \\
\hline
\end{tabular}

Eşlerin dindar olması evlilikte mutluluk için yeterlidir.

\begin{tabular}{lllllll} 
Evet & 20 & 17 & 19 & 2 & 29 & 20 \\
& $(16-20)$ & $(12-20)$ & $(9-20)$ & $(7-15)$ & $(22-30)$ & $(13-20)$ \\
Kararsiz & 20 & 17 & 18 & 11 & 28 & 19 \\
& $(14-20)$ & $(11-20)$ & $(13-20)$ & $(7-15)$ & $(21-30)$ & $(12-20)$ \\
Hayır & 20 & 16 & 19 & 11 & 29 & 19 \\
& $(13-20)$ & $(4-20)$ & $(9-20)$ & $(7-15)$ & $(19-30)$ & $(6-20)$ \\
P &, 614 &, $\mathbf{0 0 3}^{*}$ &, $\mathbf{0 0 3}^{*}$ & $\mathbf{, 0 0 6}^{*}$ & $\mathbf{0 0 1}^{*}$ & $\mathbf{0 0 1}^{*}$ \\
\hline
\end{tabular}

Tablo 1'e göre, çocuk sayısı ile dindarlık envanterinin inanç, inancin önemi, duygu ve bilgi alt boyut puanları arasinda istatistiksel olarak anlamlı bir farklılık gözlenmezken $(p>, 05)$, dindarlığın etki alt boyutu için grupların benzer olduğu belirlenmiş, ibadet alt boyutunda ise dört veya daha fazla çocuğu olanların tek çocuğu olanlara göre; üç çocuğu olanların ise bir ve iki çocuğu 
630 | Z. S. YILMAZ \& H. APAYDIN \&. B. N. YÜKSEL / Dindarlık ile Eşler Arası Uyum Arasındaki İlişkinin İncelenmesi: Kahramanmaraş Örneği

olanlara göre puanları daha yüksektir $(\mathrm{p} \leq, 05)$. Yani dindarlık arttıkça çocuk sayısı da artış göstermektedir.

Analiz sonuçları evlenme şekli ile dindarlık envanteri alt boyutları arasındaki ilişkide görücü usulüyle evlenenlerin hem kendisi tanışarak hem de tanıdıkların önerisi ile evlenenlere göre ibadet alt boyutunda daha yüksek puanlarının olduğunu $(\mathrm{p} \leq, 05)$, etki alt boyutu için ise görücü usulüyle evlenenlerin kendisi tanışarak evlenenlere göre puanlarının daha yüksek $(\mathrm{p} \leq, 05)$ olduğunu ortaya koymaktadır. Diğer alt boyutlar için ise evlilik şekline göre bir farklılaşma tespit edilememiştir $(p>, 05)$.

Bulgular, eş seçimindeki ölçüt ile dindarlık envanteri alt boyutları arasındaki ilişkide; eş seçimini dindar ve ahlâklı olma ölçütüne göre gerçekleştirenlerin; ibadet, duygu, etki alt boyutları ve toplamda zeki olmaya göre eş seçenlere göre puanlarının daha yüksek olduğunu göstermiştir $(\mathrm{p} \leq, 05)$. Diğger alt boyutlar için ise eş seçimi ölçütlerine göre puanların benzer olduğu görülmüştür $(\mathrm{p}>, 05)$.

Ulaşılan sonuçlar, "eşlerin ikisinin de dindar olması evlilikte mutluluk için yeterlidir" görüşüne katılma/ma durumu ile dindarlık envanteri alt boyutları arasındaki ilişkide; 'yeterli' olarak düşünen katılımcıların inanç hariç diğer tüm puanlarının, bu düşünceye sahip olmayanlara göre anlamlı derecede daha yüksek olduğunu belirlemiştir $(\mathrm{p} \leq, 05)$. Bununla birlikte bu grubun, inancın önemi hariç diğer alt boyutlardaki puanlarının düşünce bakımından kararsız olanlara göre daha yüksek olduğu tespit edilmiştir. İnanç boyutunda ise grupların puanlarının benzer olduğu gözlenmiştir.

\subsection{Eşler Arası Uyum ile Çeşitli Değişkenler Arasındaki İlişkilere Dair Bulgular}

$\mathrm{Bu}$ bölümde, eşler arası uyum alt boyutları (evlilikte mutluluk/evlilikte sorun) ile katılımcıların hem sosyodemografik hem de evlilik ve dindarlık ile ilgili çeşitli değişkenler arasındaki ilişkilere dair sürdürülen analizlere yer verilmektedir. 
Z. S. YILMAZ \& H. APAYDIN \&. B. N. YÜKSEL / Examining Relationship between Religiosity and Marital Adjustment: The Case Study in Kahramanmaras I 631

Tablo 2: Çeşitli Değişkenlerin Eşler Arası Uyum Alt Boyutlarına Göre Dağılımına İlișkin Analiz Sonuçları

\begin{tabular}{|c|c|c|c|}
\hline \multirow[t]{2}{*}{ I } & \multirow[t]{2}{*}{$\mathbf{J}$} & \multicolumn{2}{|c|}{ EŞLER ARASI UYUM } \\
\hline & & $\begin{array}{l}\text { Evlilikte } \\
\text { mutluluk }\end{array}$ & Evlilikte sorun \\
\hline \multirow[t]{3}{*}{ Cinsiyet } & Kadın & $70.0(12.5-100)$ & $37.5(0-96.43)$ \\
\hline & Erkek & $72.5(30.0-100)$ & $33.93(0-85.71)$ \\
\hline & $\mathrm{P}$ &, $014^{*}$ & , 054 \\
\hline \multirow[t]{7}{*}{ Yaş } & 20-25 yaş & $80.0(40.0-100)$ & 40.18 (1.79-82.14) \\
\hline & $26-30$ yaş & $75.0(25.0-100)$ & $32.14(0.00-83.93)$ \\
\hline & 31-35 yaş & $72.5(25.0-100)$ & $35.71(0.00-85.71)$ \\
\hline & $36-40$ yaş & $70.0(17.5-100)$ & $43.75(3.57-91.07)$ \\
\hline & $1-45$ yaş & $67.5(12.5-100)$ & $25.0(0.0-96.43)$ \\
\hline & +46 yaş & $65.0(27.5-100)$ & $33.93(0.0-78.57)$ \\
\hline & $\mathrm{P}$ & ,001* & ,069 \\
\hline \multirow{6}{*}{$\begin{array}{l}\text { Eğitim } \\
\text { durumu }\end{array}$} & İlkokul & $65.0(25-95)$ & $52.68(0-96.43)$ \\
\hline & Ortaokul & $66.25(30-100)$ & $43.75(0-91.07)$ \\
\hline & Lise & $72.5(12.5-100)$ & $48.21(5.36-85.71)$ \\
\hline & Üniversite & $72.5(17.5-100)$ & $30.36(0-83.93)$ \\
\hline & Yüksek lisans & $77.5(35-100)$ & $26.79(0-71.43)$ \\
\hline & $\mathrm{P}$ & ,001* & , $001^{*}$ \\
\hline \multirow[t]{4}{*}{ Gelir düzeyi } & Orta altı & $67.5(25-100)$ & $50.0(10.71-76.79)$ \\
\hline & Orta & $72.5(12.5-100)$ & $32.14(0-96.43)$ \\
\hline & Orta üstü & $75.0(17.5-100)$ & $47.32(0-91.07)$ \\
\hline & $\mathrm{P}$ &, $047^{*}$ &, $004^{*}$ \\
\hline Yaşamın & İl & $72.5(12.5-100)$ & $33.93(0-91.07)$ \\
\hline çoğunun & İlçe & $75.0(27.5-100)$ & $34.82(0-96.43)$ \\
\hline \multirow[t]{2}{*}{ geçirildiği yer } & Kasaba/Köy & $70.0(25.0-100)$ & $42.86(0-83.93)$ \\
\hline & $\mathrm{P}$ &, 576 & 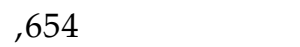 \\
\hline Çalışma & Çalışmıyor & $65.0(12.5-100)$ & $51.79(0-96.43)$ \\
\hline \multirow{4}{*}{ durumu } & İşçi & $77.5(45.0-100)$ & $43.75(0-85.71)$ \\
\hline & Memur & $75.0(17.5-100)$ & $28.57(0-83.93)$ \\
\hline & Diğer & $66.25(27.5-100)$ & $41.07(0-78.57)$ \\
\hline & $\mathrm{P}$ & &, $001^{*}$ \\
\hline \multirow[t]{4}{*}{ Eş ile yaş farkı } & Aynı yaş & $75.0(32.5-100)$ & $37.5(0-83.93)$ \\
\hline & $1-3$ yaş & $75.0(17.5-100)$ & $32.14(0-96.43)$ \\
\hline & $4-6$ yaş & $72.5(25-100)$ & $35.71(0-82.14)$ \\
\hline & $7-9$ yaş & $67.5(25-100)$ & $41.07(0-91.07)$ \\
\hline
\end{tabular}


632 | Z. S. YILMAZ \& H. APAYDIN \&. B. N. YÜKSEL / Dindarlık ile Eşler Arası Uyum Arasındaki İlişkinin İncelenmesi: Kahramanmaraş Örneği

\begin{tabular}{|c|c|c|c|}
\hline & +9 yaş & $67.5(12.5-100)$ & 51.79 (5.36-78.57) \\
\hline & $\mathrm{P}$ & 251 & ,204 \\
\hline \multirow[t]{6}{*}{ Evlilik süresi } & 1 yildan az & $85.0(42.5-100)$ & $30.36(0-78.57)$ \\
\hline & $1-3$ y1l & $72.5(40-100)$ & 33.93 (5.36-83.93) \\
\hline & $4-6$ y1l & $72.5(35-100)$ & $32.14(0-83.93)$ \\
\hline & $7-9$ y1l & $72.5(25-100)$ & $50.0(5.36-85.71)$ \\
\hline & +9 y1l & $70.0(12.5-100)$ & $35.71(0-96.43)$ \\
\hline & $\mathrm{P}$ &, $001^{*}$ &, $003^{*}$ \\
\hline \multirow[t]{6}{*}{ Çocuk sayısı } & Yok & $80.0(42.5-100)$ & $33.93(0-82.14)$ \\
\hline & 1 çocuk & $72.5(27.5-100)$ & $33.93(0-85.71)$ \\
\hline & 2 çocuk & $72.5(17.5-100)$ & 35.71 (3.57-96.43) \\
\hline & 3 çocuk & $67.5(25-100)$ & $43.75(0-91.07)$ \\
\hline & +3 çocuk & $70.0(12.5-100)$ & 32.14 (0-83.93) \\
\hline & $\mathrm{P}$ &, $012^{*}$ & ,364 \\
\hline \multirow[t]{4}{*}{ Evlenme şekli } & Görücü usulü & $70.0(12.5-100)$ & $41.07(0-85.71)$ \\
\hline & $\begin{array}{l}\text { Kendimiz } \\
\text { taniş. }\end{array}$ & $75.0(27.5-100)$ & $33.93(0-96.43)$ \\
\hline & $\begin{array}{l}\text { Tanıdık } \\
\text { önerisi }\end{array}$ & $70.0(30-100)$ & $32.14(0-91.07)$ \\
\hline & $\mathrm{P}$ &, $030^{*}$ & ,207 \\
\hline \multirow[t]{6}{*}{$\begin{array}{l}\text { Eş seçimi } \\
\text { ölçütleri }\end{array}$} & $\begin{array}{l}\text { Fiziksel } \\
\text { çekicilik }\end{array}$ & $65(17.5-100)$ & $44.64(0-96.43)$ \\
\hline & Zeki olma & $72.5(35-100)$ & $35.71(5.36-69.64)$ \\
\hline & Soylu bir aile & $65.0(25-80)$ & $51.79(14.29-82.14)$ \\
\hline & Dindar olma & $75.0(12.5-100)$ & $32.14(0-85.71)$ \\
\hline & İyi geliri olma & $57.5(37.5-97.5)$ & 71.43 (3.57-91.07) \\
\hline & $\mathrm{P}$ &, $001^{*}$ & , $001^{*}$ \\
\hline \multirow{6}{*}{$\begin{array}{l}\text { Din eğitimi } \\
\text { kaynağı }\end{array}$} & Aile & $70.0(25.0-100)$ & $42.86(0-96.43)$ \\
\hline & Okul & $77.5(47.5-100)$ & $25.0(0-78.57)$ \\
\hline & $\begin{array}{l}\text { Kur'an } \\
\text { Cami }\end{array}$ & $72.5(12.5-100)$ & $33.93(0-82.14)$ \\
\hline & $\begin{array}{l}\text { Din e. } \\
\text { almadim. }\end{array}$ & $67.5(47.5-100)$ & $42.86(16.07-78.57)$ \\
\hline & Diğer & $67.5(35.0-97.5)$ & $33.93(0-85.71)$ \\
\hline & $\mathrm{P}$ &, $011^{*}$ &, $007^{*}$ \\
\hline Çocuğun din & Evet & $72.5(12.5-100)$ & 35.71 (0-91.07) \\
\hline eğitimi & Kararsızım & 61.25 (27.5-95) & 37.5 (7.14-96.43) \\
\hline $\begin{array}{l}\text { almasini } \\
\text { isteme }\end{array}$ & $\mathrm{P}$ &, $020^{*}$ & 835 \\
\hline
\end{tabular}


Z. S. YILMAZ \& H. APAYDIN \&. B. N. YÜKSEL / Examining Relationship between Religiosity and

Marital Adjustment: The Case Study in Kahramanmaras I 633

\begin{tabular}{llll}
\hline $\begin{array}{l}\text { Dinî ortamlara } \\
\text { katılma }\end{array}$ & Katıliyorum & $75.0(12.5-100)$ & $38.39(0-91.07)$ \\
durumu & Katılmiyorum & $70.0(27.5-100)$ & $33.93(0-96.43)$ \\
& $\begin{array}{l}\text { İstiyorum, } \\
\text { eşim }\end{array}$ & $62.5(17.5-100)$ & $58.93(17.86-83.93)$ \\
& $\begin{array}{l}\text { istemiyor. } \\
\text { P }\end{array}$ &, 195 & \\
“Eşlerin & Evet & $72.5(17.5-100)$ & $42.86(0-83.93)$ \\
$\begin{array}{l}\text { ikisinin de } \\
\text { dindar olması } \\
\text { evlilikte }\end{array}$ & Kararsızım & $65.0(27.5-97.5)$ & $39.29(5.36-96.43)$ \\
$\begin{array}{l}\text { mutluluk için } \\
\text { yeterlidir" }\end{array}$ & & $75.0(12.5-100)$ & $32.14(0-85.71)$ \\
\hline
\end{tabular}

Tablo 2'de, katılımcıların sosyodemografik değişkenler ile evlilikte uyum düzeyleri arasındaki ilişki verileri gösterilmektedir. Buna göre katılımciların evlilikte mutluluk/sorun puanları ile cinsiyet ilişkisinde erkek ve kadınların mutluluk puanı ortalamaları sırasıyla 72,5 ve 70 olarak hesaplanmıştır. Buna göre erkeklerin evlilikte mutluluk puan ortalamaları kadınlara göre anlamlı derecede daha yüksek iken $(\mathrm{p}=, 014)$; evlilikte sorun puanları bakımından cinsiyetler arasında anlamlı bir farklılaşma olmadı̆̆ $(p=, 054)$ belirlenmiştir. Katılımcıların evlilikte mutluluk/sorun ile yaş grupları arasındaki ilişkisi üzerine gerçekleştirilen analiz sonuçları; yaş gruplarına göre evlilikte mutluluk puanlarının anlamlı derecede farklılaştığını $(\mathrm{p}=, 001)$, evlilikte sorun puanlarının ise anlamlı derecede farklılaşmadığını $(p=, 069)$ göstermektedir. Buna göre 20-25 ile 26-30 yaş grubu katılımcıların evlilikte mutluluk puan ortalamaları 46 yaş veya üstü katılımcılara göre daha yüksektir $(\mathrm{p}=, 05)$. Katılımciların evlilikte mutluluk/sorun puanları ile eğitim durumları arasında anlamlı bir farklılık görülmüştür $(p=, 001)$. Buna göre ilkokul mezunlarının evlilikte mutluluk puanları, üniversite ve yüksek lisans mezunlarının puanlarından anlamlı derecede daha düşükken $(p \leq, 05)$; yüksek lisans mezunlarının evlilikte sorun puanları ilkokul, ortaokul ve lise mezunlarından, üniversite mezunlarının evlilikte sorun puanları ise ilkokul ve lise mezunlarının puanlarından anlamlı derecede daha düşüktür $(p \leq, 05)$. Verilere göre katılımcıların eşler arası uyum ve gelir düzeyleri arasındaki ilişkinin anlamlı olduğu görülse de 
634 | Z. S. YILMAZ \& H. APAYDIN \&. B. N. YÜKSEL / Dindarlık ile Eşler Arası Uyum Arasındaki İlişkinin İncelenmesi: Kahramanmaraş Örneği

$(\mathrm{p}=, 047)$, ikili karşılaştırmalar sonucunda gruplar arasında istatistiksel olarak anlamlı bir fark bulunmamıştır ( $\mathrm{p}>, 05)$. Buna göre ortanın altı gelire sahip olanların evlilikte sorun ortalamaları orta düzey gelire sahip katılımcılardan daha yüksektir $(p \leq, 05)$. Bununla birlikte yaşamın çoğunun geçirildiği yer ile eşler arası uyum arasında da anlamlı bir ilişki tespit edilemezken çalışma durumuna göre evlilikte mutluluk ve sorun puanlarının farklılaştı̆̆ 1 belirlenmiştir $(\mathrm{p}=, 001)$. Çalışmayanların evlilikte mutluluk puanları işçi ve memurlara göre; diğer grubunun evlilikte mutluluk puanları ise işçilere göre daha düşüktür $(\mathrm{p} \leq, 05)$. Son olarak memurların diğer gruplara göre evlilikte sorun puanları daha düşüktür $(\mathrm{p} \leq, 05)$.

Tablo 2; katılımciların evlilikte uyum düzeyleri ile evlilik değişkenleri arasındaki ilişkilere dair verileri göstermektedir. Analiz sonuçlarına göre katılımcıların eşler arası uyum puanlarının eş ile yaş farkı durumuna göre farklılaştığ 1 ve hem evlilikte mutluluk $(p=, 251)$ hem de sorun puanları karşılaştırıldığında her iki puan için de istatistiksel olarak anlamlı bir fark olmadığ edilmiştir $(p=, 204)$. Evlilik süresine göre evlilikte mutluluk puanlarının ise farklılaştığı ve 1 yıldan daha az süredir evli olanların 4 yıl veya daha fazla süredir evli olanlara göre evlilikte mutluluk puanlarının daha yüksek olduğu belirlenmiştir $(p \leq, 05)$. Evlilikte sorun puanları dikkate alındığında ise 7-9 yıldır evli olanların 1 yıldan daha az süredir evli olanlara göre; 4-6 yıldır evli olanların 10 yıl veya daha fazla süredir evli olanlara göre daha yüksek puanları olduğu gözlenmiştir $(p \leq, 05)$. Evlilikteki mutluluk ve soruna çocuk sayısının etkisi incelendiğinde ise aralarında anlamlı bir farklılaşma olduğu belirlenmiştir. Buna göre; çocuğu olmayan ve üç çocuklu olan ailelerin evlilikte daha mutlu olduğu görülürken evlilikte sorun ile çocuk sayısı arasında ise bir ilişki bulunamamıştır. Evlilik değişkeninden bir diğeri olan evlilik şekline göre evlilikte mutluluk puanlarının ise farklılaştığ $(p=, 030)$, evlilikte sorun puanlarının ise benzer olduğu $(p=, 207)$ belirlenmiştir. Sonuçlara göre; tanışarak evlenenlerin görücü usulüyle evlenenlere göre evlilikte mutluluk puanları daha yüksektir. Yukarıdaki tabloda katılımcıların eş seçerken dikkat ettikleri ölçütlere göre mutluluk puanları da incelenmiş ve puanların farklılaştığı görülmüştür $(p=, 001)$. Fiziksel çekicilik ve soylu bir aileden gelmeye göre eş 
seçenlerin, zeki olma ve dindar olmaya göre eş seçenlerden evlilikte mutluluk puanlarının daha düşük olduğu $(\mathrm{p} \leq, 05)$; dindar ve ahlâklı olmaya göre eş seçenlerin ise iyi gelir sahibi olmaya göre seçenlerden evlilikte sorun puanlarının daha düşük olduğu belirlenmiştir $(\mathrm{p} \leq, 05)$.

Son olarak, katılımcıların evlilikte uyum düzeyleri ile dindarlık değişkenleri arasındaki ilişkilere dair veriler; din eğitimi kaynağ1 değişkenine göre evlilikte mutluluk $(p=, 011)$ ve sorun $(p=, 007)$ puanlarında farklılaşma olduğunu; ailede dinî eğitim alanların okulda dinî eğitim alanlara göre evlilikte mutluluk puanlarının daha düşük, evlilikte sorun puanlarının ise daha yüksek olduğunu belirlemiştir $(p \leq, 05)$. Yukarıdaki tabloda çocuğunun dinî eğitim almasını isteme değişkenine göre mutluluk puanları da incelendiğinde, katılımcılardan çocuğunun dinî eğitim almasını isteme/me durumuna göre evlilikte mutluluk puanlarının farklılaştığı $(p=, 020)$ ve çocuğunun dinî eğitim almasını isteyenlerin kararsız olanlara göre evlilikte mutluluk puanlarının daha yüksek olduğu; evlilikte sorun puanlarının ise benzer $(p=, 853)$ olduğu görülmüştür. Katılımcıların dinî ortamlara katılma durumlarına göre evlilikte mutluluk $(p=, 195)$ ve sorun $(p=, 076)$ puanlarında istatistiksel olarak anlamlı bir fark olmadığı; eşler arası uyum ile "eşlerden her ikisinin dindar olması evlilikte mutluluk için yeterlidir" görüşüne katılma arasındaki ilişkide ise "Kararsızım" yanıtını verenlerin "Evet" veya "Hayır" yanıtını verenlere göre evlilikte mutluluk puanlarının daha yüksek olduğu tespit edilmiştir $(p \leq, 05)$. İlgili ifadeye "Hayır" yanıtını verenlerin ise diğer iki yanıtı verenlere göre evlilikte sorun puanlarının daha düşük olduğu görülmüştür ( $\mathrm{p} \leq, 05)$.

\subsection{Dindarlık ile Eşler Arası Uyum Düzeyi Arasındaki İlişlere Dair Bulgular}

$\mathrm{Bu}$ bölümde araştırmadaki katılımcıların dindarlık envanteri ile eşler arası uyum düzeyleri arasındaki ilişkilere dair sürdürülen analiz sonuçlarına yer verilmektedir. 
636 | Z. S. YILMAZ \& H. APAYDIN \&. B. N. YÜKSEL / Dindarlık ile Eşler Arası Uyum Arasındaki İlişkinin İncelenmesi: Kahramanmaraş Örneği

Tablo 3: Dindarlık Envanteri Alt Boyutlarına Göre Eşler Arası Uyum Toplam Puanlarına İlişkin Spearman Korelasyon Analizi Sonuçları

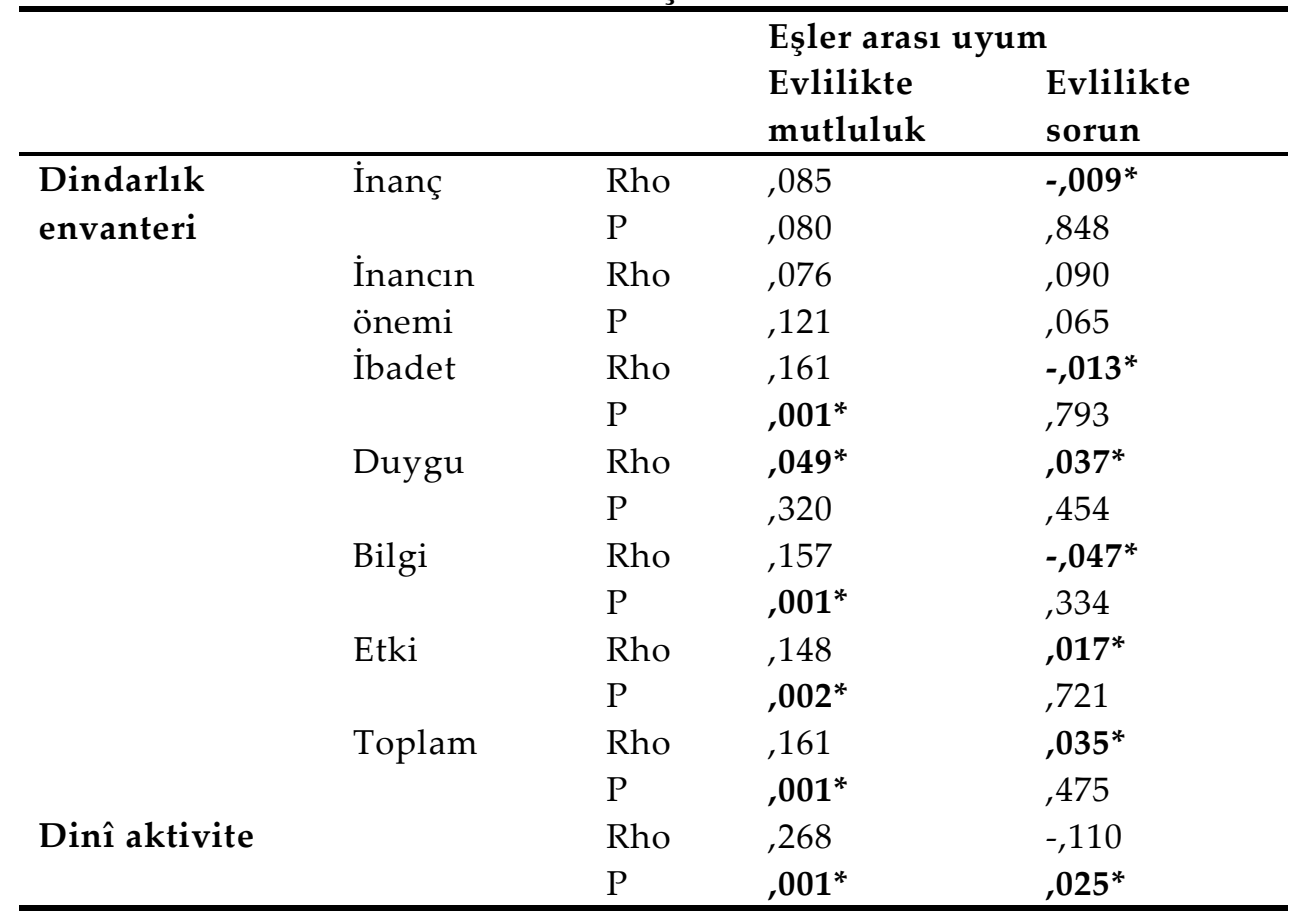

Tablo 3; eşler arası uyum (evlilikte mutluluk/evlilikte sorun) puanları ile dindarlık envanteri (inanç/inancın önemi/ibadet/duygu/bilgi/etki) ve dinî aktivite puanları arasındaki ilişkileri belirlemek için yapılan Spearman korelasyon analizi sonuçlarını göstermektedir. Buna göre; evlilikte mutluluk toplam puanları ile dindarlık envanterinin ibadet, bilgi, etki alt boyutları arasında anlamlı düzeyde pozitif bir ilişki ( $\mathrm{p} \leq, 05)$; evlilikte mutluluk toplam puanları ile dinî aktivite puanları arasında ise daha kuvvetli yönde anlamlı bir ilişki olduğu tespit edilmiştir $\left(\mathrm{rho}^{2}, 268\right)$. Bununla birlikte evlilikte sorun toplam puanları ile dindarlık envanteri puanları arasında istatistiksel olarak anlamlı bir ilişki gözlenmezken ( $\mathrm{p}>, 05)$; evlilikte sorun toplam puanları ile dinî aktivite puanları arasında oldukça negatif yönde anlamlı bir ilişki olduğu görülmüştür (rho=-,110). 


\section{Sonuç, Tartışma ve Öneriler}

Marital Adjustment: The Case Study in Kahramanmaras I 637

Dindarlık ile eşler arası uyum arasındaki ilişkiyi konu edinen bu araştırmada; öncelikle cinsiyet, yaş, eğitim durumu, gelir düzeyi gibi sosyodemografik değişkenler, evlilik ve dindarlık değişkenleri ile hem dindarlık hem de eşler arası uyum arasındaki ilişkiler ele alınmış ve son olarak dindarlık ile eşler arası uyum (evlilikte mutluluk/evlilikte sorun) arasındaki ilişki incelenmiştir.

Araştırmada elde edilen bulgulara göre, dindarlık düzeyleri çocuk sayısına bağlı olarak anlamlı düzeyde farklılaşmaktadır. Dindarlığın ibadet boyutu dişındaki diğer boyutları ile çocuk sayısı arasında anlamlı bir fark gözlenmezken, ibadet alt boyutunda 4 veya daha fazla çocuğu olanların tek çocuğu olanlara göre; 3 çocuğu olanların bir ve iki çocuğu olanlara göre dindarlık-ibadet puanlarının daha yüksek olduğu görülmektedir. Rowthorn'un aktardığına göre $(2011,2519)$ dünyanın 82 ülkesinde inanç ve çocuk sayısı arasındaki ilişkiyi saptamak için yaptığı çalışma sonuçları haftada birden fazla ibadet yapan bireylerde ortalama çocuk sayısı 2,5; ayda ortalama bir kez ibadet yapanlarda 2,01; dindarlığ yaşam biçimi haline getirmiş tarikatlarda ortalama çocuk sayısı 6,2; hiçbir dine bağlı olmayanlarda ise ortalama çocuk sayısı 1,67 olduğunu belirtmektedir. Araştırmamızda; "dindarlık ile çocuk sayısı arasında pozitif bir ilişki vardır" hipotezi kısmen doğrulanmıştır.

Araştırma sonucu elde edilen bulgular, görücü usulüyle evlenenlerin kendisi tanışarak veya tanıdıkların önerisiyle evlenenlere göre dindarlık-ibadet alt boyutu puanının daha yüksek olduğunu belirlemiştir. Dindarlık-etki alt boyutu için görücü usulüyle evlenenlerin kendisi tanışarak evlenenlere göre puanları daha yüksektir. Sonuç olarak; bulgular doğrultusunda "görücü usulü ile evlenenler tanışarak evlenenlerden daha dindardır" alt hipotezi kısmen doğrulanmıştır.

Katılımcıların eş seçme kriterleri ile dindarlık arasındaki ilişkiye dair gerçekleştirilen analizde; kendilerini ve eşlerini dindar olarak niteleyenlerin eş seçimlerinde de "dindar ve ahlâklı" kriterine dikkat ettikleri görülmektedir. Yapılan çalışmalarda da benzer sonuçlara ulaşılmıştır. Bilgin (2000, 568-569) tarafından gerçekleştirilen bir çalışmada, evli erkek katılımcıların \%46,3'ünün eş tercihinde sırasıyla kadının "dindar olması" ve kişilik kriterlerine 
638 | Z. S. YILMAZ \& H. APAYDIN \&. B. N. YÜKSEL / Dindarlık ile Eşler Arası Uyum Arasındaki İlişkinin İncelenmesi: Kahramanmaraş Örneği

dikkat ettikleri görülürken, evli kadın katılımcıların birincil olarak aradıkları özellikler ise sırasıyla "kişilik" $(\% 47,9)$ ve "dindarlık" $(\% 23,6)$ şeklinde sıralanmıştır. Bener'in $(2011,74)$ çalışmasında da üniversite öğrencilerinin eş seçiminde dikkat ettikleri en önemli ölçütün dindarlık $(\% 37,6)$ olduğu tespit edilmiştir. Sonuçlar birlikte değerlendirildiğinde; "eş seçiminde dindarlık kriterini tercih edenler diğer kriterlere göre eş seçenlerden daha dindardır" hipotezi doğrulanmıştır.

Dindarlık ve "eşlerden her ikisinin dindar olması evlilikte mutluluk için yeterlidir" fikrine katılım arasındaki ilişkiye dair bulgular; katılımcıların \%75'inin eş seçiminde "dindar ve ahlâklı" ölçütüne dikkat ettiklerini, dindar bireylerin eş seçiminde dindarlık kriterine önem vermelerine rağmen dindarlığ 1 evlilikte mutluluk için yeterli olarak görmediklerini ortaya çıkarmaktadır. Konuyla ilgili yapılan çalışma sonuçları da bunu desteklemektedir. Bener'in $(2011,78)$ araştırmasında dindarlık ile hem "eşlerden her ikisinin dindar olması evlilikte mutluluk için yeterlidir" fikri hem de "eşlerin dinî algılama ve anlama biçimlerinin farklı oluşu, başlı başına bir geçimsizlik sebebidir" fikri arasında pozitif ilişki ve dindarlık ile başka dinden birisiyle evlenme fikri arasında ise negatif bir ilişki olduğunu ortaya koymuştur. Yine benzer bir bulguya Karslı'nın $(2018,249)$ çalışmasında ulaşılmış ve dinî değer, dinî bilinç, dinî davranış ile mutluluk arasında pozitif yönlü anlamlı ilişkilerin olduğu tespit edilmiştir. Bu tespit çalışmamızda da doğrulanmış ve dindarlık arttıkça "eşlerden ikisinin de dindar olması evlilikte mutluluk için yeterlidir" fikrine katılım azalmıştır.

Araştırma sonuçlarında; evlilikte uyum ile sosyodemografik değişkenler arasındaki ilişkilere dair anlamlı değerlere ulaşılmış ve eşler arası uyum düzeyinin cinsiyete göre farklılaştığı; erkeklerin kadınlara göre eşler arası uyum düzeyinin daha yüksek olduğu belirlenmiştir. $\mathrm{Bu}$ aralık düzeyinin anlamlı derecede farklılaşmasının sebebi; kadınların daha duygusal ve derin bir birliktelik arayışı içinde, erkeklerin daha somut ve ihtiyaç odaklı olarak evlilik hayatını sürdürmek istemeleri olabilir. Bu bakımdan eşler arası uyumda kadınlar daha çok zorlanmakta iken erkekler için günlük hayatın akışının bozulmaması bu uyumun sürdürülmesi için yeterlidir. Ayrıca kadınlar evlilikteki sorunları erkeklere göre daha 
etkin ve yoğun olarak hissettiklerinden bu sonuç doğal karşılanmaktadır. Yapılan araştırmalarda benzer sonuçlara ulaşılmıştır (Arvas - Hökelekli, 2017, 138; Üncü, 2007, 82; Güngör, 2007, 115). Bununla birlikte cinsiyet değişkeni ile evlilik doyumu arasında anlamlı bir farklılığın olmadığı sonucuna varan çalışmalar da mevcuttur (Berk, 2009, 68). Belirtilen ilişki üzerine yapılan ilk araştırmalarda kadınların uyum göstermeye erkeklerden daha eğilimli olduğu tespit edilse de son yıllarda yapılan çalışmalarda ise uyumun cinsiyete bağlı çok az bir farklılık gösterdiği ortaya koyulmuştur. Kadınlarda uyum oranının yüksek çıkmasının sebebinin ise toplumsal rollerin ve beklentilerin olduğu düşünülmektedir (Kağıtçıbaşı, 2004, 87-88). Bu doğrultuda çalışmada; "kadınların erkeklere göre evlilik uyum puanları daha yüksektir" hipotezi ters yönden doğrulanmıştır.

Çalışmada, eşler arası uyumun yaş gruplarına göre farklılaştığı; 20-25 ile 26-30 yaş grubu katılımcılarının 46 yaş veya üstü katılımcılarına göre evlilikte mutluluk puanlarının daha yüksek olduğu bulunmuştur. Yapılan çalışmalarda da benzer sonuçlara ulaşılmış ve bireylerin yaşlarının ilerlemesi ile evlilikte mutluluk arasında negatif ilişkinin var olduğu belirlenmiştir (Almas, 2010, 65-66; Kara, 2013, 49-50; Arvas - Hökelekli, 2017, 139). Ancak bu çalışmada "eşler arası uyum ile yaş arasında pozitif bir ilişki vardır" hipotezi doğrulanmış kabul edilmektedir.

Eğitim seviyesi ile eşler arası uyum ilişkisinde bulgular; ilkokul mezunlarının üniversite ve yüksek lisans mezunlarına göre evlilikte mutluluk puanlarının daha düşük olduğunu; yüksek lisans mezunlarının ilkokul, ortaokul ve lise mezunlarına göre; üniversite mezunlarının ise ilkokul ve lise mezunlarına göre evlilikte sorun puanlarının daha düşük olduğunu ortaya koymaktadır. Eğitim düzeyi arttıkça evlilikte mutluluk puanları artmakta; evlilikte sorun puanları ise azalmaktadır. Literatürde eğitim düzeyindeki artışın evlilikte mutluluk ile pozitif ilişkili olduğu çalışmalar bulunmakta iken (Almas, 2010, 65); değişkenler arası farkın anlamlılık düzeyine ulaşmadığ 1 çalışmalara da rastlanmaktadır (Kışlak - Çabukça, 2002, 39). Veriler doğrultusunda bu çalışmada; "eşler arası uyum ile eğitim seviyesi arasında pozitif bir ilişki vardır" hipotezinin doğrulandı̆̆ 1 görülmektedir. 
640 | Z. S. YILMAZ \& H. APAYDIN \&. B. N. YÜKSEL / Dindarlık ile Eşler Arası Uyum Arasındaki İlişkinin İncelenmesi: Kahramanmaraş Örneği

Gelir düzeyi ile eşler arası uyum arasındaki ilişkiye dair sonuçlar; gelir düzeyi ile evlilikte mutluluk arasında anlamlı bir ilişki belirlemezken, evlilikte sorun ile negatif bir ilişki tespit etmektedir. İmamoğlu ve Yasak $(1997,221)$ araştırmalarında benzer sonuçlar elde etmişler ve bu durumu yüksek sosyoekonomik durumun bireylerdeki bağımlılık duygusunu azaltmasına, duygusal bağlılık ile birbiriyle ilgili olmayı arttırmasına ve sonuç olarak çiftler arasında evlilik doyumunu yükseltmesine bağlamışlardır. Sonuçta bulgular, "eşler arası uyum ile gelir düzeyi arasında negatif bir ilişki vardır" hipotezini kısmen doğrulamaktadır.

Araştırma sonucuna göre sosyodemografik değişkenlerden yaşamın çoğunun geçirildiği yer ile eşler arası uyum arasında da herhangi bir anlamlı ilişki tespit edilememiştir. Buna göre değişkenler arası ilişkisizlik durumundan dolayı; "eşler arası uyum ile yaşamın çoğunun geçirildiği yerin nüfusu arasında negatif ilişki vardır" hipotezimiz doğrulanmamıştır.

Araştırma verileri; gelir düzeyi ile eşler arası uyum arasındaki ilişkide orta düzey gelire sahip katılımcıların ortanın altında gelire sahip olanlara göre evlilikte daha düşük sorun puanlarının olduğunu göstermektedir. Ayrıca meslek grupları ile eşler arası uyum arasındaki ilişkide çalışmayan katılımcıların işçi ve memurlara göre; diğer grubunun da işçilere göre evlilikte mutluluk puanlarının daha düşük olduğu belirtilmektedir. Çalışmamızda ulaştığımız anlamsal ilişkiye rağmen literatürdeki çalışmaların çoğunda bireylerin evlilik uyumlarının meslek gruplarına göre farklılaşmadığı sonucuna ulaşılmıştır (Kışlak - Çabukça, 2002, 39; Demiray, 2006, 21; Kublay - Oktan, 2015, 30). Bazı çalışmalarda ise çalışan kadınların daha uyumlu evliliklere sahip oldukları belirtilmektedir (Nathawat - Mathur, 1992, 353; Çilli vd., 2004, 2).

Çalışma sonuçlarına göre; eşler arası uyum ile eşler arası yaş farkı ilişkisinde istatistiksel olarak anlamlı bir farkın olmadığ 1 tespit edilmiştir. Ancak yapılan çalışmaların çoğunda eşler arasındaki yaş farkı ile evlilikte mutsuzluk arasında yüksek düzeyde anlamlı ilişki olduğu belirlenmiştir. Bu doğrultuda; "eşler arası uyum ile yaş farkı arsında negatif ilişki vardır" hipotezimiz doğrulanmamıştır.

Araştırma bulgularına göre, eşler arası uyumun evlilik süresi ile ilişkisinde, bir yıldan daha az süredir evli olanların dört yıl veya 
daha fazla süredir evli olanlara göre evlilikte mutluluk puanlarının yüksek olduğu gözlenmiştir. Literatürdeki çalışmalara bakıldığında benzer sonuçlara ulaşıldığı görülmektedir (Demiray, 2006, 45; Çelik, 2009, 80-81; Almas, 2010, 66; Kublay - Oktan, 2015, 30). Bu çalışmaların yanı sıra evlilik süresi ile eşler arası uyum arasında anlamlı bir ilişkinin bulunmadığı, diğer bir deyişle evlilik süresinin eşler arası uyumu etkilemediği sonucuna ulaşan çalışmalar da mevcuttur (Kışlak - Çabukça, 2002, 39). Evliliğin ilk yıllarında eşlerin sevgi ve uyum açısından açık ve istekli olmaları durumuna karşıllk ortalama dört yıldan sonra eşlerin uyumunda bir düşüş gözlenmiştir. Bununla birlikte evliliğin onuncu yılından itibaren ise eşlerin birbirlerini kabullendikleri ve aile hayatlarının olgunlaşması ile birlikte uyumun arttığı görülmektedir. Sonuç olarak; "eşler arası uyum ve evlilik süresi arasında pozitif bir ilişki vardır" hipotezi kısmen doğrulanmış sayılmaktadır.

Evlilikte mutluluk ve çocuk sayısı arasında ilişkiye dair yapılan analiz sonuçları anlamlı bir ilişkinin olduğunu ve hem çocuğu olmayan hem de 3 çocuklu olan ailelerin diğerlerine kıyasla evlilikte daha mutlu olduğunu göstermektedir. Bu konuda yapılan başka araştırmalarda birbirinden farklı sonuçlara ulaşılmıştır. Buna göre evlilikte mutluluk ile çocuk sayısı arasında anlamlı herhangi bir ilişkinin bulunmadığı (Fışıloğlu, 1992, 19-20; Kocadere, 1995, 141; Kışlak - Çabukça, 2002, 39) veya negatif bir ilişkinin bulunduğu yani çocuk sayısının artması ile evlilik doyumunun azaldığını belirten çalışmalar mevcuttur (Fidanoğlu, 2006, 135; Çelik, 2009, 8586; Almas, 2010, 66). Bu sonuçlar doğrultusunda "eşler arası uyum ile sahip olunan çocuk sayısı arasında pozitif bir ilişki vardır" hipotezimizin kısmen doğrulandığ 1 düşünülmektedir.

Araştırma sonucuna göre, eş seçme kriterleri ile evlilikte uyum arasındaki ilişkide; katılımcıların evlenme şekline göre evlilikte mutluluk puanlarının farklılaştığı, evlilikte sorun puanlarının ise benzer olduğu belirlenmiştir. Buna göre tanışarak evlenenlerin görücü usulüyle evlenenlere göre evlilikte mutluluk puanları daha yüksektir. Yapılan çalışmalarda benzer sonuçlara ulaşılmıştır (Demir - Fişıloğlu, 1999, 230; Akar, 2005, 63; Çelik, 2009, 77-78). Sonuçlar birlikte değerlendirildiğinde evliliğini kendi seçimi ile gerçekleştirenlerin evlilik uyumunun daha yüksek olduğu 
642 | Z. S. YILMAZ \& H. APAYDIN \&. B. N. YÜKSEL / Dindarlık ile Eşler Arası Uyum Arasındaki İlişkinin İncelenmesi: Kahramanmaraş Örneği

görülmektedir. Netice olarak çalışma sonuçlarına göre "tanışarak evlenenlerin görücü usulü ile evlenenlere göre eşler arası uyumu daha fazladır" hipotezi doğrulanmıştır.

Eş seçim kriterleri ile eşler arası uyum arasındaki ilişkide anlamlı sonuçlara ulaşılmış ve eş seçiminde dindar/ahlâklı olma ölçütüne dikkat edenlerin evlilikte mutluluk puanlarının fiziksel çekicilik ve soylu bir aileden gelmeyi dikkate alanlara göre daha yüksek olduğu belirlenmiştir. Dindar ve ahlâklı olmaya göre eş seçenlerin iyi gelir sahibi olmaya göre eş seçenlere göre evlilikte sorun puanları daha düşüktür. Sonuç olarak çalışmamızda, "eş seçiminde dindar ve ahlâklı olma ölçütünü seçenlerin eşler arası uyum puanı daha yüksektir" hipotezi doğrulanmıştır.

Bulgulara göre, din eğitimi alınan yer ve eşler arası uyum ilişkisinde; din eğitimi kaynağı değişkenine göre evlilikte mutluluk ve sorun puanlarında farklılaşma olmakta; ailede dinî eğitim alanların okulda dinî eğitim alanlara göre evlilikte mutluluk puanları daha düşük, evlilikte sorun puanları ise daha yüksektir. Buna göre okulda dinî eğitim almak eşler arası uyumu olumlu yönde etkilemektedir. Bu doğrultuda çalışmada "dinî eğitimini okulda alanların eşler arası uyum puanları daha yüksektir" hipotezi doğrulanmaktadır.

Araştırma sonucuna göre, çocuğunun dinî eğitim almasını isteme durumu ile eşler arası uyum arasındaki ilişkide; çocuğunun dinî eğitim almasını isteyen katılımcıların kararsızlara göre evlilikte mutluluk puanları daha yüksek olarak belirlenmiştir. Çocuğun dinî yöneliminin ilk oluştuğu ortam ailedir. $\mathrm{Bu}$ sebepten bireyin çocukluk döneminden itibaren iç çatışma yaşamadan bilinçli bir dinsel tercihte bulunabilmesinin yolu ailesinin çocuğa nasıl bir yaklaşım sergilediği ile doğrudan ilişkilidir (Apaydın, 2001, 327332). Bu doğrultuda çalışmamızda da "çocuğunun dinî eğitim almasını isteyenlerin eşler arası uyum puanı daha yüksektir" hipotezinin doğrulandığı görülmektedir.

Eşler arası uyum ile dinî aktivite arasındaki ilişkide; evlilikte mutluluk ile dinî aktivite puanları arasında pozitif bir ilişki tespit edilmiştir. Literatürdeki veriler de bu sonucu doğrulamaktadır (Lambert - Dollahite, 2006, 607). Ayrica dinî/mezhepsel farklılıklardan kaynaklı dinî aktivite farklılıklarının da evlilikte 
sorunu artırdığını tespit eden çalışmalar mevcuttur (Call - Heaton, 1997, 382; Dollahite vd., 2004, 820-821). Buna göre "dinî aktivite gerçekleştiren eşler arası uyum puanı daha yüksektir" hipotezinin doğrulandığ 1 kabul edilmektedir.

Eşler arası uyum ile "eşlerden her ikisinin dindar olması evlilikte mutluluk için tek başına yeterlidir" ifadesine katılım arasındaki ilişkide, bu ifadeye "kararsızım" yanıtını verenlerin "evet" veya "hayır" yanıtını verenlere göre evlilikte mutluluk puanlarının daha yüksek olduğu belirlenmiştir. İlgili ifadeye "hayır" yanıtını verenlerin diğer iki yanıtı verenlere göre evlilikte sorun puanlarının daha düşük olduğu görülmüştür. Bu sonuçla "'eşlerden her ikisinin dindar olması evlilikte mutluluk için tek başına yeterlidir' ifadesine 'evet' yanıtını veren eşler arası uyum puanı daha yüksektir" hipotezi doğrulanmamıştır.

Araştırmanın temel hipotezi olan; "dindarlık ile eşler arası uyum arasında pozitif bir ilişki vardır" önermesi inanç ve tecrübe boyutları dışında diğer boyutlar açısından doğrulanmıştır. Bununla birlikte dindarlık ile evlilikte sorun puanı arasında istatistiksel olarak anlamlı bir ilişki gözlenmemiştir. Sonuçta; çalışmada çok dindar veya dindar eşi olanların, az dindar veya dindar olmayan eşi olanlara göre daha yüksek mutluluk puanı olduğu görülmüştür. Literatürdeki sınırlı sayıda gerçekleştirilen çalışmalar da mevcut pozitif ilişkiyi doğrulamaktadır. Karslı konu üzerine gerçekleştirdiği iki çalışmasında da $(2018,249 ; 2019,173)$ dindarlık ile mutluluk ve ilişki memnuniyeti arasında pozitif ilişkiler tespit etmiştir. Yurtdışında yapılan çalışmalarda da dindarlık ve eşler arası uyumda dindarlığın evlilikteki mutluluğu sağlayan en önemli etkenlerden biri olduğu saptanmıştır (Call - Heaton, 1997, 382; Sullivan, 2001, 21; Fard vd., 2013, 309; Geçioğlu - Kayıklık, 2019, 211-212). Dindarlık puanı yüksek olan çiftlerin daha mutlu ve evliliklerinin daha sağlam olduğu yani ayrılma ve aldatma gibi durumlara daha az yöneldikleri tespit edilmiştir (Almas, 2010, 153). Bununla birlikte dindarlık ile mutluluk ve yaşam memnuniyeti arasında pozitif ilişkilerin bulgulandığ çalışmalar da mevcuttur (Chang, 2009, 1; Abdelkhalek, 2009, 803). Araştırma sonuçları birlikte değerlendirildiğinde; bireysel olarak evlilikte mutlulukla doğrudan bağlantılı olarak karşılıklı saygı, bağışlama, sevgi ve 
644 | Z. S. YILMAZ \& H. APAYDIN \&. B. N. YÜKSEL / Dindarlık ile Eşler Arası Uyum Arasındaki İlişkinin İncelenmesi: Kahramanmaraş Örneği

sadakat gibi durumların dinlerde övülen özellikler olmasının ve bu yüzden evlilikte mutluluğu etkileyen kişilik özellikleriyle de dindarlığı etkileyen özelliklerin ilişkili olmasının bu pozitif ilişkiyi sağladığı düşünülmektedir.

Sonuç olarak araştırma ile; dindarlık düzeyi yüksek olarak belirlenen evli çiftlerin evliliklerinde mutluluk düzeylerinin yüksek olduğu, evlilik hayatlarıyla dinî inançlarını bütünleştirdikleri ve evlilikte sorunlara sebep olan durumları daha az yaşadıkları görülmektedir.

Dindarlık ve eşler arası uyum ilişkisi üzerine gerçekleştirilen bu çalışma verileri ışığında; ideal dinî tutum ve davranışları sergileyenlerin aynı zamanda evlilikte sorunlara sebep olabilecek davranışlara düşmemeleri için bireylerde bir kontrol mekanizması oluşturduğu görülmekte ve bu açıdan ailelerin dindarlık açıdan bilinçlendirilmesi önem taşımaktadır. Bununla birlikte dindarlık bakımından eşlerin birbirlerine uyum düzeyleri evlilik içi sorunlar incelenirken de gözden kaçırılmamalı ve eşlere danışmanlık ile rehberlik hizmeti verenlerin eşlerin dindarlık seviyelerini de irdelemeleri tavsiye edilmektedir. Evlilikteki sorunlar sürecinin yanı sıra evlilik öncesi de bireylerin aile danışmanlarından hizmet alması sağlanmalıdır.

Sosyal psikoloji açısından bakıldığında, Diyanet İşleri Başkanlığg'nın Aile İrşat ve Rehberlik Bürosu da çalışmalarında aile içi sorunların çözülmesi, ailevi konularda motivasyon arttırılmasına yönelik faaliyetlerinin daha etkin yürütülmesi için aile ve dindarlık ile ilgili çalışmaları dikkate almalıdır. Bu açıdan eşlerin dindarlıkları ve uyumlarının incelenmesi ve sorunların tespiti ile ailelere daha etkin bir danışma ve rehberlik hizmeti verilebileceği düşünülmektedir. Çalışmamızın yanı sıra gerek şehir ve kırsal kesimden elde edilen bulguların karşılaştırıldı̆̆ı; gerekse eşler arası farklılaşma ve değişim ile etkilendiği düşünülen değişkenler açısından derinlemesine araştırmalar yapılmalıdır. 
Z. S. YILMAZ \& H. APAYDIN \&. B. N. YÜKSEL / Examining Relationship between Religiosity and Marital Adjustment: The Case Study in Kahramanmaras | 645

\section{Kaynakça}

Abdelkhalek, Ahmed. "Religiosity, Subjective Well-Being, and Depression in Saudi Children and Adolescents". Mental Health, Religion and Culture 12/8 (2009), 803-815.

Akar, Hülya. Psikiyatrik Yardım Talebi Olanlar ile Yardım Talebi Olmayan ve Boşanma Aşamasında Olan Çiftlerde; Çift Uyumu ve Kişilik Özellikleri Arasındaki İlişkinin Karşılaştırılması. İstanbul: İstanbul Üniversitesi, Tıp Fakültesi, Tıpta Uzmanlık Tezi, 2005.

Almas, Gülşen. Evlilikte Uyum ve İnanç Gelişimi Arasındaki İlişkiler. Sivas: Cumhuriyet Üniversitesi, Sosyal Bilimler Enstitüsü, Yüksek Lisans Tezi, 2010.

Apaydın, Halil - Kirman, Mehmet Ali. "İlahiyat Fakültesi Öğrencilerinin Eş Seçim Biçimleri ve Karşı Cinsle Arkadaşlık İlişkileri Üzerine Psikososyal Bir Yaklaşım: Kahramanmaraş Örneği". KSÜ İlahiyat Fakültesi Dergisi 2/4 (2004), 97-114.

Apaydın, Halil. "Aile İçi İletişimin Çocuğun Dinsel Gelişimine Etkisi". Ondokuz Mayıs Üniversitesi Illahiyat Fakültesi Dergisi 12/12-13 (2001), 319-337.

Arvas, Fatma Balcı - Hökelekli, Hayati. “Dindarlık ile Evlilik Doyumu ve Evlilikte Sorun Çözme İlişkisi Üzerine Bir İnceleme". Değerler Ĕ̆itimi Dergisi 15/34 (2017), 129-160.

BASAGM, Başbakanlık Aile ve Sosyal Araştırmalar Genel Müdürlügü. Türkiye'de Aile Değerleri Araştırması. Ankara, 2010.

Bener, Muhammet. Dindarlık ve Eş Seçimi İlişkisi: SDÜ Örneği. Isparta: Süleyman Demirel Üniversitesi, Sosyal Bilimler Enstitüsü, Yüksek Lisans Tezi, 2011.

Berk, Melis. Evli Öğretmenlerin Yükleme Tarzları ve Evlilik Doyum Algılarının Bazı Demografik Değişkenler Açısından Incelenmesi. Adana: Çukurova Üniversitesi, Sosyal Bilimler Enstitüsü, Yüksek Lisans Tezi, 2009.

Bilgin, Vejdi. "Türk Toplumunun Evlilik Konusunda Bilgilenme ve Bilinçlenme Düzeyleri". Uludă̆ Üniversitesi İlahiyat Fakültesi Dergisi 9/9 (2000), 565-588.

Call, Vaughn - Heaton, Tim. 1997. "Religious Influence on Marital Stability". Journal for the Scientific Study of Religion 36/3 (1997), 382392.

Cebeci, Suat. Dinî Danışma ve Rehberlik. Ankara: DİB Yayınları, 2012. 
646 | Z. S. YILMAZ \& H. APAYDIN \&. B. N. YÜKSEL / Dindarlık ile Eşler Arası Uyum Arasındaki İlişkinin İncelenmesi: Kahramanmaraş Örneği

Chang, Wen Chun. "Religious Attendance and Subjective WellBeing in An Eastern-Culture Country: Empirical Evidence from Taiwan". Marburg Journal of Religion 14/1 (2009), 1-30.

Çatak, Bilge Deniz. Mezhep Farklılıklarının Eşler Arası Ilişsilere Etkileri. Antalya: Akdeniz Üniversitesi, Sosyal Bilimler Enstitüsü, Yüksek Lisans Tezi, 2012.

Çelik, Eyüp. Evli Öğretmenlerin Bağlanma Stili, Denetim Odağı ve Bazı Nitelikleri Açısından Evlilik Uyum Düzeylerinin İncelenmesi. Eskişehir: Anadolu Üniversitesi, Eğitim Bilimleri Enstitüsü, Yüksek Lisans Tezi, 2009.

Çilli, Ali Savaş vd.. “Ev Kadınlarında ve Çalışan Evli Kadınlarda Psikolojik Belirtilerin Karşılaştırılması". Genel Tıp Dergisi 14/1 (2004), 1-5.

Demir, Ayhan - Fışıloğlu, Hürol. "Loneliness and Marital Adjustment of Turkey Couples". The Journal of Psychology 133/2 (1999), 230-240.

Demiray, Özlem. Evlilikte Uyumun Demografik Özelliklere Göre İncelenmesi. Diyarbakır: Dicle Üniversitesi, Sosyal Bilimler Enstitüsü, Yayımlanmamış Yüksek Lisans Tezi, 2006.

Demirkan, Semra. "Türk Ailesinin Korunması ve Güçlendirilmesinde Sivil Toplum Kuruluşları ile İşbirliğinin Önemi". Aile ve Toplum 3/9 (2006), 91-95.

Dollahite, David vd.. "Families and Religious Beliefs, Practices, and Communities: Linkages in a Diverse and Dynamic Cultural Context". Handbook of Contemporary Families: Considering the Past, Contemplating the Future. ed. Marilyn Coleman vd.. 411-431. CA: SAGE Publications, 2004.

Fard, Mohammad Khodayari vd.. "Religiosity and Marital Satisfaction". Social and Behavioral Sciences 82 (2013), 307-311.

Fişıloğlu, Hürol. "Lisansüstü Öğrencilerin Evlilik Uyumu”. Türk Psikolojisi Dergisi 7/28 (1992), 16-23.

Fidanoğlu, Oya. Evlilik Uyumu ile Eşlerin Somatizasyon Düzeyleri Arasındaki İlişki ve Diğer Sosyodemografik Değişkenler Açısından Karşılaştırılması. İstanbul: Marmara Üniversitesi, Sağlık Bilimleri Enstitüsü, Yüksek Lisans Tezi, 2007.

Fidanoğlu, Oya. Evlilik Uyumu, Mizah Tarzı ve Kaygı Düzeyi Arasındaki İlişki. İstanbul: Marmara Üniversitesi, Eğitim Bilimleri Enstitüsü, Yüksek Lisans Tezi, 2006. 
Z. S. YILMAZ \& H. APAYDIN \&. B. N. YÜKSEL / Examining Relationship between Religiosity and Marital Adjustment: The Case Study in Kahramanmaras I 647

Geçioğlu, Ahmet Rıfat - Kayıklık, Hasan. “Dindarlık ve Evlilik Uyumu İlişkisi: Evli Bireyler Üzerine Bir İnceleme". Çukurova Üniversitesi Ilahiyat Fakültesi Dergisi 19/1 (2019), 202-224.

Goodman, Michael vd.. "Religious Faith and Transformational Processes in Marriage". Family Relations: An Interdisciplinary Journal of Applied Family Studies 62/5 (2013), 808-823.

Güngör, Hüdanur Cihan. Evlilik Doyumunu Açıklamaya Yönelik Bir Model Geliştirme. Ankara: Gazi Üniversitesi, Eğitim Bilimleri Enstitüsü, Doktora Tezi, 2007.

İmamoğlu, Emine Olcay - Yasak, Yeşim. “Dimensions of Marital Relationships as Perceived by Turkish Husbands and Wives". Genetic Social and General Psychology Monographs 123/2 (1997), 221232.

Johnstone, Ronald. Religion in Society. New Jersey: Prentice Hall, 1992.

Kağıtçıbaşı, Çiğdem. Yeni İnsan ve İnsanlar. İstanbul: Evrim Yayınevi, 2004.

Kara, Nihal. Çiftlerde Yükleme Biçimleri, Çatışma Çözme Stilleri ve Eşin Duygu Dışavurum Tarzları ile Çift Uyumu Arasındaki İlişkilerin Incelenmesi. İstanbul: Haliç Üniversitesi, Sosyal Bilimler Enstitüsü, Yüksek Lisans Tezi, 2013.

Karslı, Necmi. "Psikolojik İyi Oluş ve Dindarlık İlişkisi: Trabzon İlahiyat Örneği". Recep Tayyip Erdoğan Üniversitesi İlahiyat Fakültesi Dergisi 15 (2019), 173-205.

Karslı, Necmi. Mutluluk ve Dindarlık. Kayseri: Kimlik Yayınları, 2018.

Kışlak, Şennur Tutarel - Çabukça, Fazlı. "Empati ve Demografik Değişkenlerin Evlilik Uyumu ile İlişkisi". Aile ve Toplum Dergisi 2/5 (2002), 35-41.

Kocadere, Müge. İyi ve Kötü Evliliklerin Özelliklerini Belirlemeye Yönelik Betimsel Bir Çalışma. İzmir: Ege Üniversitesi, Sağlık Bilimleri Enstitüsü, Yüksek Lisans Tezi, 1995.

Köktaş, Mehmet Emin. Türkiye'de Din̂̂ Hayat. İstanbul: İşaret Yayınları, 1993.

Kublay, Deniz - Oktan, Vesile. "Evlilik Uyumu: Değer Tercihleri ve Öznel Mutluluk Açısından İncelenmesi". Türk Psikolojik Danışma ve Rehberlik Dergisi 5/44 (2015), 25-35.

Kula, Naci. Kimlik ve Din. İstanbul: Ayışığı Kitapları, 2001. 
648 | Z. S. YILMAZ \& H. APAYDIN \&. B. N. YÜKSEL / Dindarlık ile Eşler Arası Uyum Arasındaki İlişkinin İncelenmesi: Kahramanmaraş Örneği

Lambert, Nathaniel - Dollahite, David. "How Religiosity Helps Couples Prevent, Resolve and Overcome Marital Conflict". Family Relations 55/4 (2006), 439-449.

Nathawat, Surenda Singh - Mathur, Asha. "Marital Adjustment and Subjective Wellbeing in Indian-Educated Housewives and Working Women". The Journal of Psychology 127/3 (1992), 353-358.

Rowthorn, Robert. "Religion, Fertility and Genes: A Dual Inheritance Model". The Royal Society 278 (2011), 2519-2527.

Sayar, Kemal. Ruh Hali. İstanbul: Timaş Yayınları, 2011.

Sevindik, Durmuş. Orta Yaş Bireylerde Dindarlık ve Mutluluk İlişkisi. Isparta: Süleyman Demirel Üniversitesi, Sosyal Bilimler Enstitüsü, Yüksek Lisans Tezi, 2015.

Sullivan, Kieran. "Understanding the Relationship Between Religiosity and Marriage: an Investigation of the Immediate and Longitudinal Effects of Religiosity on Newlywed Couples". Journal of Family Psychology 15/4 (2001), 610-628.

Şener, Arzu - Terzioğlu, Günsel. “Bazı Sosyoekonomik ve Demografik Değişkenler ile İletişimin Eşler Arası Uyuma Etkisinin Araştırılması". Aile ve Toplum Dergisi 10/4 (2008), 7-20.

Tarhan, Nevzat. Evlilik Psikolojisi-Öncesiyle Sonrasıla Evlilik. İstanbul: Timaş Yayınları, 2013.

Taş, Kemalettin. “Dindarlı̆̆ın Kriterleri Üzerine Tipolojik Bir Araştırma". Dindarlığın Sosyo-Psikolojisi. ed. Ünver Günay Celaleddin Çelik. Adana: Karahan Yayınları, 2006.

Üncü, Serap. Duygusal Zekâ ve Evlilik Doyum İlişkisi. Ankara: Ankara Üniversitesi, Eğitim Bilimleri Enstitüsü, Yayımlanmamış Yüksek Lisans Tezi, 2007. 